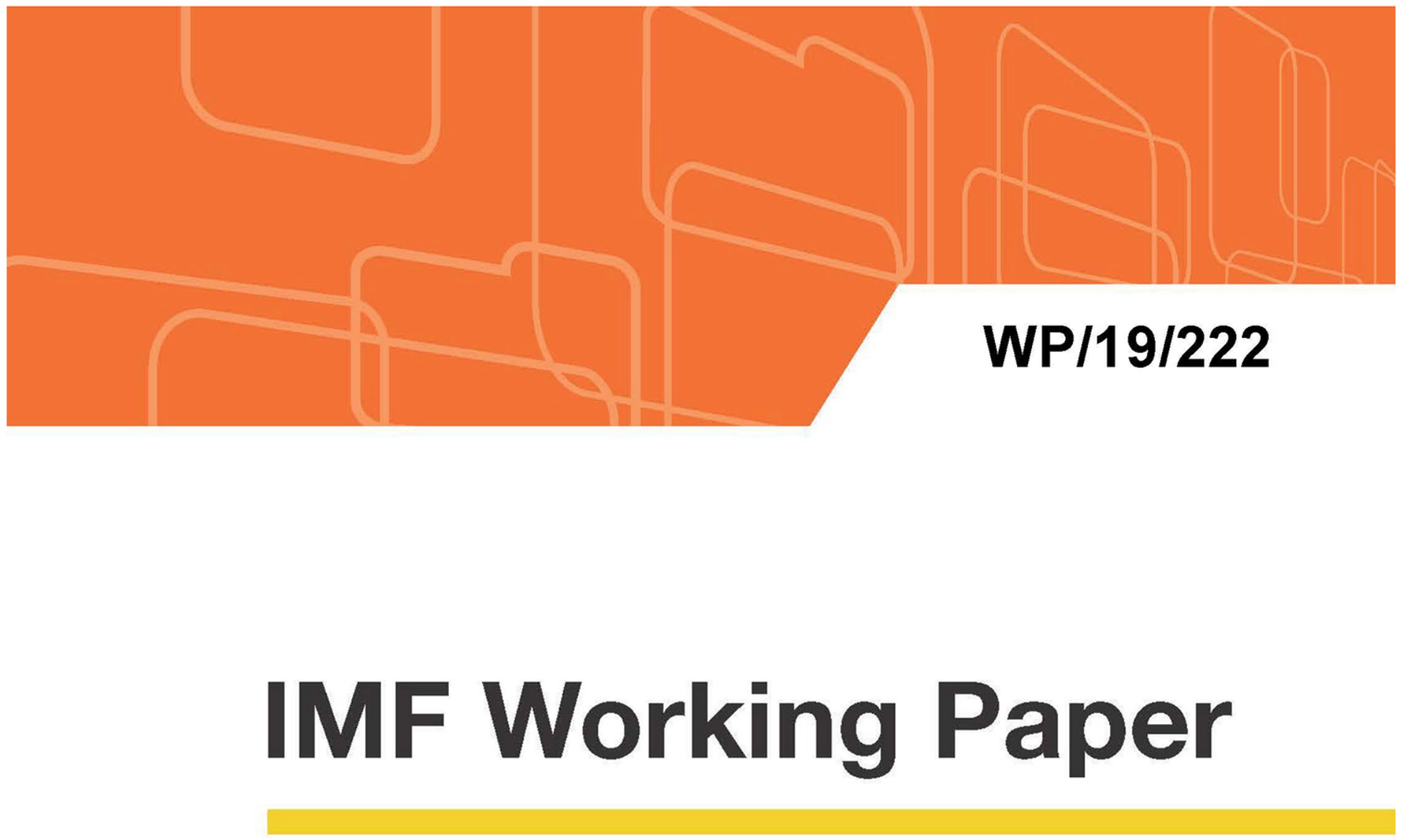

\title{
The Macroeconomic Effects of Labor and Product Market Reforms in Morocco
}

By Babacar Sarr, Mokhtar Benlamine, and Zsuzsa Munkacsi

IMF Working Papers describe research in progress by the author(s) and are publis hed to elicit comments and to encourage debate. The views expressed in IMF Working Papers are those of the author(s) and do not necessarily represent the views of the IMF, its Executive Board, or IMF management.

$$
\text { I N T E R N A T I O N A L M O N E T A R Y F U N D }
$$




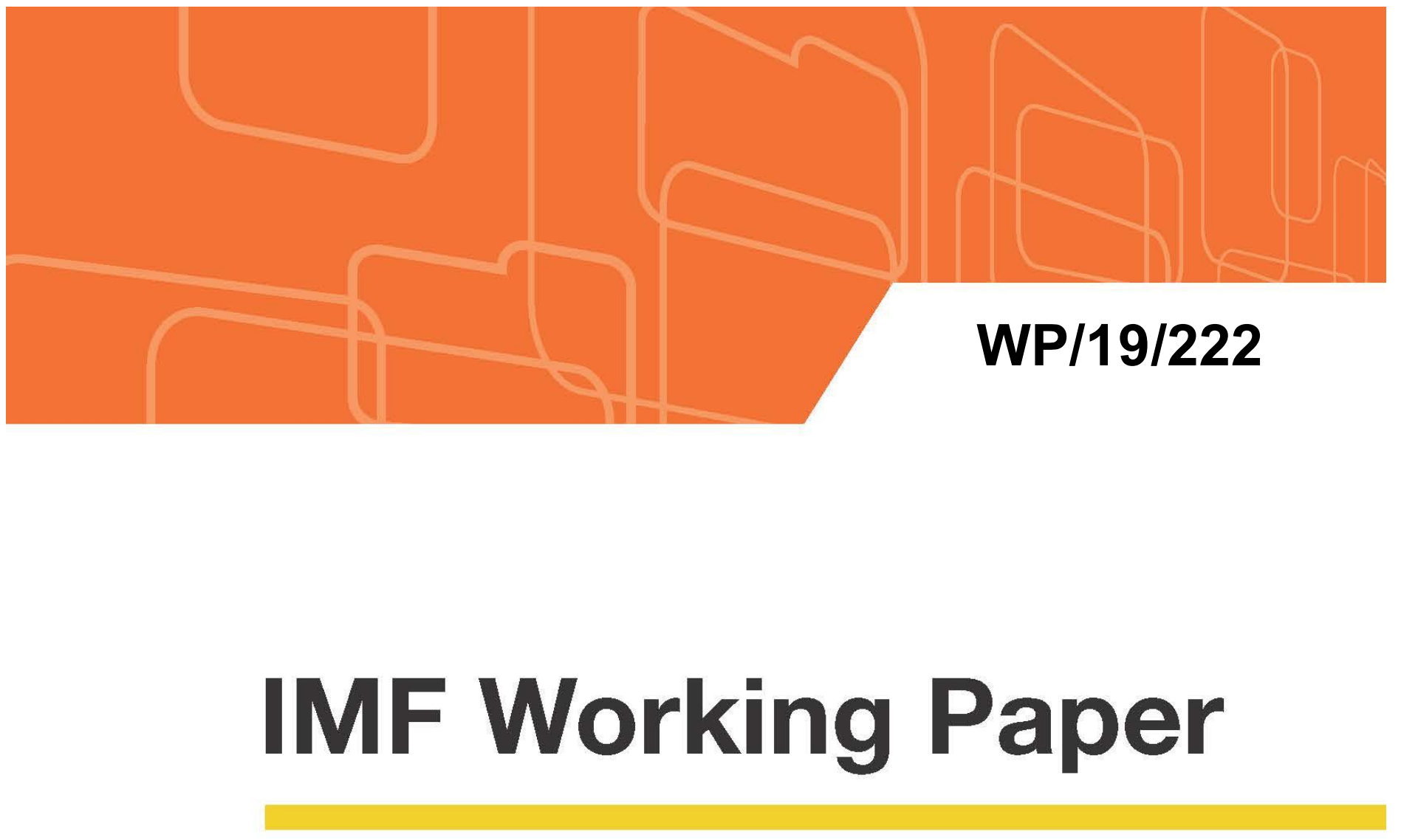

\section{The Macroeconomic Effects of Labor and Product Market Reforms in Morocco}

By Babacar Sarr, Mokhtar Benlamine, and Zsuzsa Munkacsi

IMF Working Papers describe re search in progress by the author(s) and are publis hed to e licit comments and to encourage de bate.

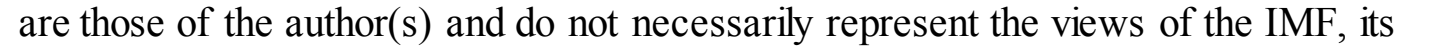

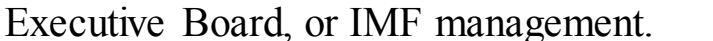

I N T E R N A T I O N A L M O N E T A R Y F U N D 


\title{
IMF Working Paper
}

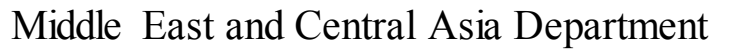

The Macroeconomic Effects of Labor and Product Market Reforms in Morocco Prepared by Babacar Sarr, Mokhtar Benlamine and Zs uzs a Munkacsi ${ }^{1}$

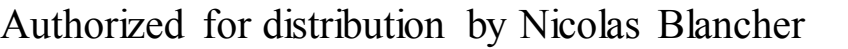

October

IMF Working Papers des cribe re search in progress by the author(s) and are publis hed to

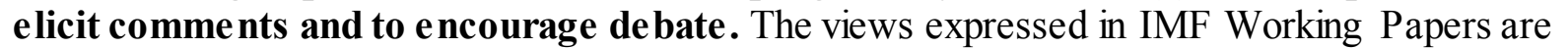

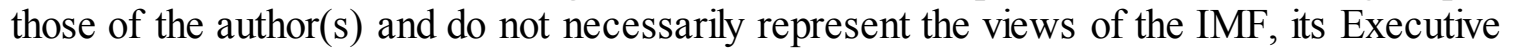

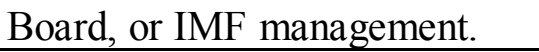

\begin{abstract}
Abs tract

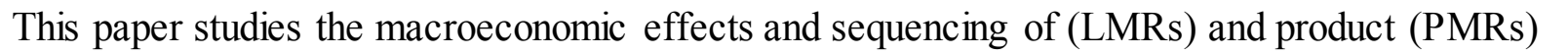

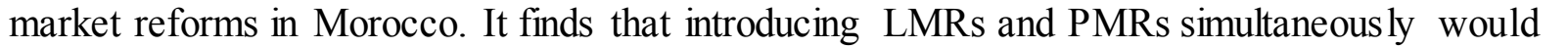

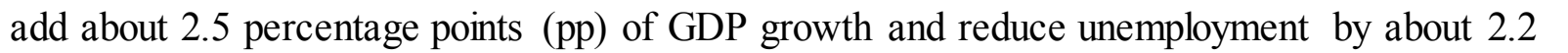

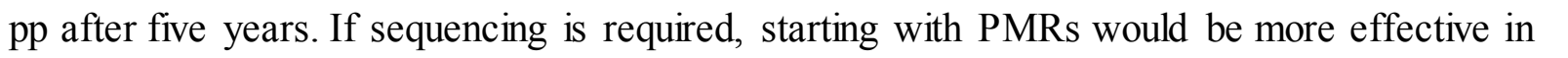

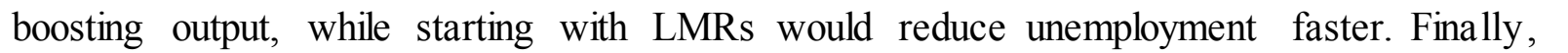

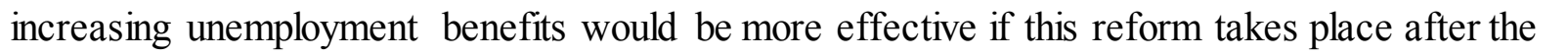

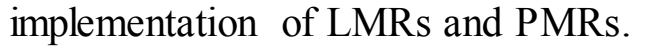

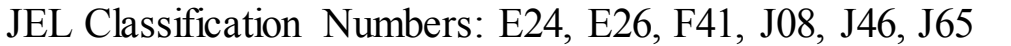

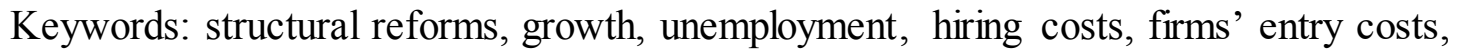

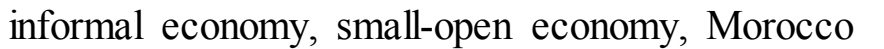

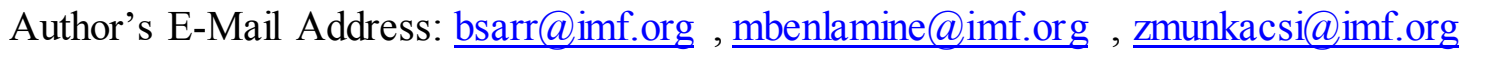

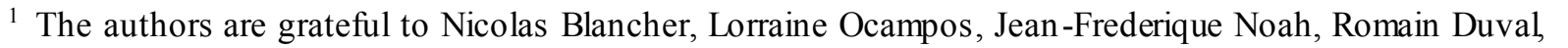

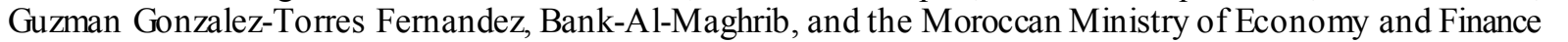

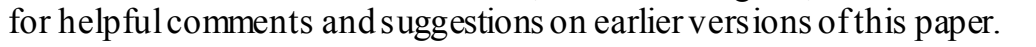

(CInternational Monetary Fund. Not for Redistribution 


\section{Table of Contents}

ABSTRACT

I. INTRODUCTION

II. MACROECONOMIC EFFECTS OF STRUCTURAL REFORMS: BRIEF OVERVIEW OF THE LITERATURE — $\underline{5}$

III. RECENT TRENDS IN GROWTH AND JOB CREATION IN MOROCCO___ $\underline{6}$

A. Economic Growth__

B. The Growth-Employment Nexus __ $\underline{7}$

IV. KEY CONSTRAINSTS IN THE LABOR MARKET ___ $\underline{8}$

A. Education and Training _ _ 8

B. Labor Market Regulations __ $\underline{8}$

C. The Informal Economy__ 9

V. KEY CONSTRAINTS IN THE BUSINESS ENVIRONMENT ___ 10

A. Access to credit and payment delays ___

B. Competition and Corruption __ 11

VI. EMPIRICAL APPROACH AND MAIN FINDINGS__

A. Key Features of the Model __

B. Main Findings _ 14

VII. CONCLUSION _

VIII. REFERENCES __ $\underline{23}$

IX. APPENDICES _

Annex I. Structure of the Model__ 25

Annex II. Evaluating the Steady State of the Model___

Annex III. Calibration of Steady State Parameters __

Annex IV: Measuring the Size of the Informal Economy in Morocco ___ 35 


\section{INTRODUCTION}

While substantial reforms have been
undertaken by the Moroccan authorities in
the last two decades, promoting job-rich
growth has proven challenging. Domestic and
external vulnerabilities were significantly
reduced, and the authorities have taken strong
policy actions to improve macroeconomic
conditions. However, economic growth has been
volatile and not strong enough to significantly
reduce unemployment. This is partly due to
relatively low and volatile total factor
productivity (TFP) growth, which has slowed
since the global financial crisis (Figure 1).

Raising Morocco's growth potential and reducing unemployment will require prompt and consistent implementation of well-sequenced structural reforms. In 2017, the government planned for ambitious structural reforms on several fronts, including the education system, the labor market, the business environment, and public sector governance. ${ }^{2}$ As a general principle, great attention needs to be paid to the coordination and sequencing of reforms, while considering their distributional impacts. ${ }^{3}$ Indeed, insufficient policy coordination could lead to either blockages from various stakeholders, or incoherent public policies. A credible reform strategy is even more desirable in a context where the authorities may lack the political and public support needed to implement some difficult reforms. Aware of these challenges, the government strengthened the strategic coordination and execution of reforms with the creation of a dedicated commission placed directly under the authority of the Head of government in 2017.

This paper assesses the potential reaction of output and employment to different reform scenarios in Morocco. We focus on two broad reform categories emphasized in the literature as having significant potential for promoting growth and employment in emerging markets: (i) reduction of firm's barriers to entry, and (ii) improvement in labor market policies and human capital. We also explore the impact of increasing unemployment benefits in the context of these reforms. More specifically, a dynamic general equilibrium model with informal product and labor markets is used to study the impacts of single, combined, and sequenced sets of reforms, while considering the transitional dynamics when the economy moves to a new equilibrium. In doing so, we can measure the benefits and costs of structural reforms in Morocco with the goal of identifying the most welfare-enhancing package of reforms, as well as quantifying their short- and mediumterm effects on output and unemployment.

\footnotetext{
2 These reforms are to contribute to the government's objectives of raising economic growth to $4.5-5.5$ percent and reducing unemployment to 8.5 percent by 2021 .

${ }^{3}$ See IMF (2017) for the distributional impacts of macro-structural policies. $\square$
} 


\title{
II. MACROECONOMIC EFFECTS OF STRUCTURAL REFORMS: BRIEF OVERVIEW OF THE LITERATURE
}

\begin{abstract}
The macroeconomic impact of structural reforms has been the focus of a large theoretical and empirical literature. Various types of structural reforms are covered in the literature, and this section focuses mainly on labor market reforms (LMRs) and product market reforms (PMRs). TFP is generally found to be one of the main channels through which structural reforms affect growth. With regard to product markets, several studies find robust evidence that low market competition slows productivity growth (Égert, 2017; Dabla-Norris and others, 2016). Liberalizing product markets can improve efficiency and boostjob creation. When businesses are faced with onerous or inconsistent regulatory enforcement and corruption, they have an incentive to hide their activities in the underground economy (Singh and others, 2012). In addition to PMRs, a vast literature documents the impacts of labor market institutions and policies on output and employment. Cacciatore and others (2012) predicts that lower firing costs lead to an increase in unemployment in the initial year after the reform, but this effect is quickly reversed in subsequent years. While labor market deregulation generally appears to have a smaller positive impact on TFP than PMRs (Bouis and Duval, 2011), some studies find that stringent employment protection does lower productivity growth (Cette and others, 2014; Bassanini and others, 2009). Muravyev (2014) claims that more rigid labor market institutions tend to negatively affect employment rates of more disadvantaged workers (women, less educated, and the youth), and could lead to greater labor market segmentation and informality.
\end{abstract}

The literature also addresses the appropriate timing and sequencing of reforms. Reform coordination and sequencing matter because the impact of a specific policy may depend on other policies implemented at the same time. Bordon and others (2016) show that gains from LMRs tend to be offset in the first few years by a greater rate of job destruction if reforms are implemented during periods of economic slack. Munkacsi and Saxegaard (2017) explore reform packages and sequencing in South Africa and find that both LMRs and PMRs increase output, and that combining them reduces short-term costs. They suggest that it is usually preferable to start with LMRs as they have a shorter period of adjustment. Anand and Khera (2016) also find that combining LMRs and PMRs has greater impact on output and employment and leads to lower informality.

Several studies attempted to quantify the macroeconomic impact of structural reforms in Morocco. IMF (2011) finds that greater labor market flexibility could reduce unemployment in Morocco by about 1.5 to 3.5 percentage points over the medium term. IMF (2013) and IMF (2016) assess that the growth gain from undertaking a full range of structural reforms might come close to 2.5 percentage points. IMF (2018) identifies several institutional frictions that hinder labor reallocation, including restrictions on the use of fixed-term contracts, firing, and working-hours flexibility, and concludes that addressing these frictions would promote labor reallocation towards higher productivity sectors, raising productivity growth and employment. World Bank (2018) highlights the need to foster inclusion as a crucial factor to attain a higher level of economic growth and job creation in Morocco. This entails more inclusive market and public institutions, greater human capital formation, and more opportunities for all citizens, particularly youth and women. 


\section{RECENT TRENDS IN GROWTH AND JOB CREATION IN MOROCCO}

\section{A. Economic Growth}

GDP growth averaged about 5 percent in the 2000s thanks to strong physical capital accumulation, broadly favorable external conditions, and the implementation of adequate macroeconomic and institutional reforms. Output was less volatile compared to previous decades as economic diversification reduced vulnerabilities to weather shocks. At the same time, Extreme poverty was eradicated, and health and educational outcomes improved, though significant social and spatial inequalities persisted. The effects of the global financial crisis (GFC) on the Moroccan economy have been relatively limited for several reasons, including: strong domestic demand, which has compensated in part for the fall in global demand; the financial sector's limited exposure to international markets; fiscal space due to declining public debt and sound government finances, necessary for adopting countercyclical policies aimed at stimulating growth; and price stability because of the exchange rate regime, i.e., the dirham pegged to a basket of currencies composed of the Euro and the Dollar. Furthermore, considerable progress has been achieved in trade liberalization, with the reduction of nominal tariffs and the signature of several trade agreements.

However, since the GFC, Morocco's solid macroeconomic performance has been challenged by a combination of domestic vulnerabilities and external shocks. Growth slowed and averaged 3.6 percent between 2010 and 2017, reflecting the impact of some external factors (slowdown in Europe and higher commodity prices), social pressures (starting with the Arab Spring protests in 2011), and structural rigidities that slowed productivity growth. The fiscal and external positions deteriorated relatively to the 2000s: gross international reserves averaged about eight months compared to about five months of imports since then, and public debt increased to reach 65.1 percent of GDP in 2017. These difficulties highlighted the slow pace of deep structural changes of the Moroccan economy despite the already implemented reforms, and the need to significantly improve productivity, without which the Moroccan economy runs the risk of slowing GDP growth over the medium term and thus falling into the middle-income trap. As a result, Morocco took steps to further increase export diversification and competitiveness; preserve external sustainability with continued fiscal consolidation; and introduce further structural reforms. Their reform efforts were supported by three successive PLL arrangements with the IMF. ${ }^{4}$

In light of these developments, a debate has emerged on Morocco's growth model. Recent trends highlight the slow pace of structural changes in the Moroccan economy and the need to significantly improve productivity. "The national development model no longer responds to citizens' growing demands and pressing needs; it has not been able to reduce disparities between

\footnotetext{
${ }^{4}$ A fourth two-year arrangement under the PLL for SDR 2.15 billion (about US\$3 billion) was a pproved in December 2018. Morocco's first PLL arrangement for SDR 4.1 billion (about US $\$ 6.2$ billion at the time of approval) was app roved on August 3, 2012; the second PLL arrangement for SDR 3.2 billion (about US $\$ 5$ billion at the time of approval) was approved on July 28, 2014; and the third PLL arrang ement for SDR 2.5 billion (about US $\$ 3.5$ billion at the time of approval) was approved on July 22, 2016.
} 
segments of the population, correct inter-regional imbalances or achieve social justice." ${ }^{5}$ The authorities pointed out that a new growth model for Morocco should guarantee the effective ness of rights, the reduction of social and territorial inequalities, and the consolidation of social cohesion, and required a structural transformation of the economy to strengthen its capacity to create jobs and improve competitiveness.

\section{B. The Growth-Employment Nexus ${ }^{6}$}

Despite sustained growth, unemployment has not declined significantly since the early 2000s (Figure 2 Job creation, most of which has taken place in the private sector, has not been sufficient to absorb the growing share of the working-age population. Additionally, the dynamism of job creation in the private sector has not significantly outpaced that of the public sector ${ }^{7}$. The working-age population grew faster than the labor force, which resulted in a decline in the labor force participation rate by more than 6 percentage points between 2000 and 2018 (from 53.1 percent to 46.2 percent). A sharp gender gap is also persistent in the labor market, with female labor force participation remaining particularly low at 22.2 percent in 2018.

Unemployment has hovered around 10 percent in the last decade. Youth is the category of population affected by the highest unemployment rate (26 percent), followed by graduates (17.1 percent). Underemployment is also as high as unemployment at around 10 percent (16.1 percent for the youth). Therefore, 33 percent of the youth are either under- or unemployed. This ratio reaches 50 percent in urban areas.
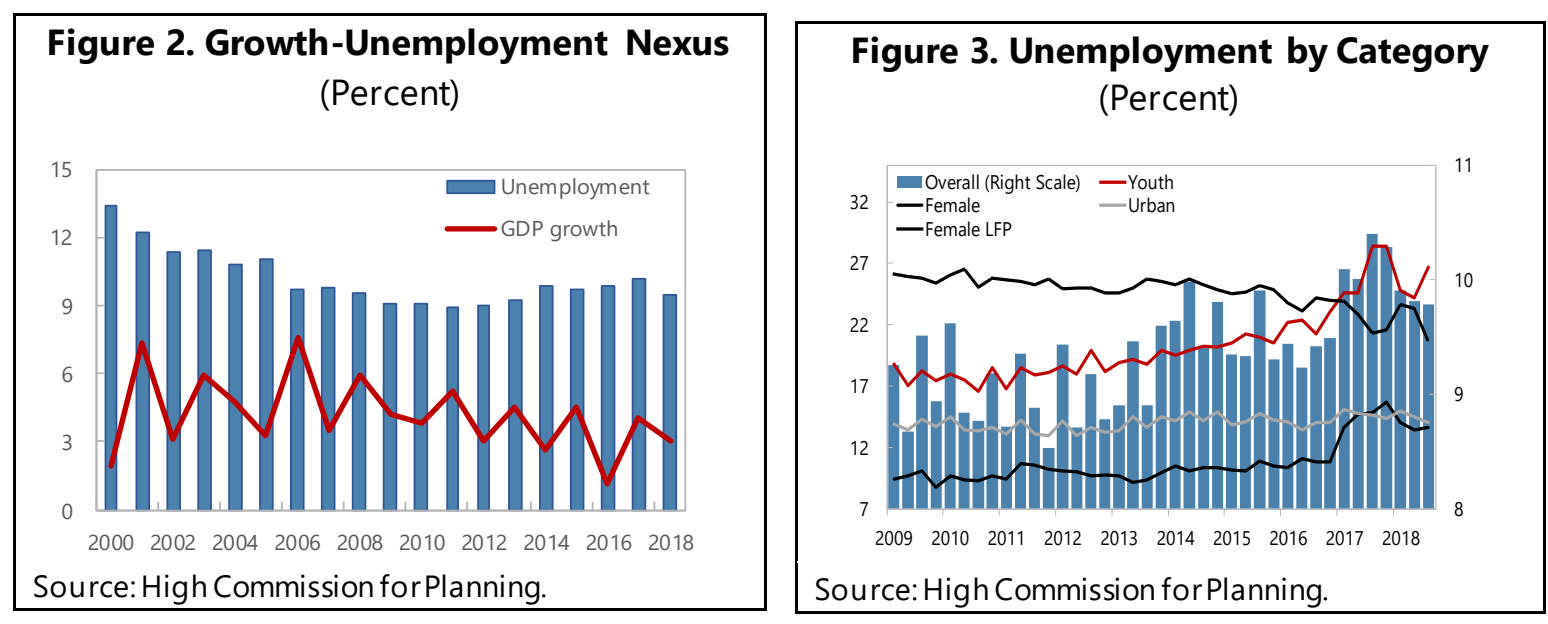

\footnotetext{
${ }^{5}$ His Majesty King Mohamed VI, excerpt from the speech during the parliament's opening session (October 2017). http://www.chambredesrepresentants.ma/fr/discours-royaux/sm-le-roi-mohammed-vi-prononce-un-discourslouverture-de-la-premiere-session-de-la

${ }^{6}$ The figures in this section are from the HCP national employment survey (2017).

7 The private sector represents about 88 percent of total employment in Morocco. Between 2005 and 2015, private sector job creation increased by 11. 2 percent, against 8.2 percent in the public sector (Rapport détaillé sur l'activité, I'emploi et le chômage, HCP, 2015).
} 


\section{KEY CONSTRAINSTS IN THE LABOR MARKET}

\section{A. Education and Training}

There is a stark contrast in Morocco between high education spending, poor educational outcomes, and unemployment (IMF, 2016). The 2017 national employment survey reveals an overrepresentation of untrained or poorly educated workers, and only a minority of highly educated workers. About 63 percent of employed people are without a diploma (45.2 percent in urban areas compared to 81.7 percent in rural areas), whereas higher-level graduates represent only 11.4 percent. Low learning outcomes and early dropouts continue to remain serious challenges (World Bank, 2018). A crucial hurdle for the educational system is related to the mismatches between tertiary training and the skills needed in the labor market. This could indirectly affect hiring costs as employers may need to provide on-the-job training to new workers.

To reduce skill mismatches, Morocco has increasingly relied on improving and extending the vocational training system, with a significant jump in both the number of trainees and the network of institutions. Consequently, Morocco's ratio of vocational trainees is higher than the MENA region average (Boudarbat and Egel, 2014). Despite these efforts, job prospects for vocational training graduates remain weak. Indeed, the unemployment rate among trainees is quite high at 24.5 percent in 2017 compared to 16 percent for general education graduates. Furthermore, the unemployment rate increases with the level of vocational training received. For vocational training graduates employed, 33 percent of them (compared to 11 percent of those in general education) occupy positions at levels below their qualification.

\section{B. Labor Market Regulations}

Labor market regulations are relatively restrictive in Morocco and may discourage job creation (Figure 4). For instance, there are important restrictions to the use of fixed-term contracts, which are only allowed in cases where the employment relationship cannot fit in an indefinite framework. ${ }^{8}$ Furthermore, the maximum contract duration is one year, renewable only once in limited cases. After this period, companies must switch to open-ended contracts. Regarding firing regulations, the labor code stipulates that only serious professional misconduct may justify dismissal (with a few exceptions), and unfair dismissal procedures introduce considerable uncertainty for employers, potentially hindering labor demand. Finally, Morocco has a high ratio of minimum to average wages compared to neighboring countries (World Bank, 2018), and in 2015, the minimum wage in urban areas represented almost 100 percent of national income per capita, which is high by international standards (HCP, 2017).

\footnotetext{
${ }^{8}$ Fixed-term contacts can be used when replacing another employee whose employment contract is in suspension, unless the latter is due to a strike; when there's a temporary increase of the company's business; or when the work is strictly seasonal.
} 


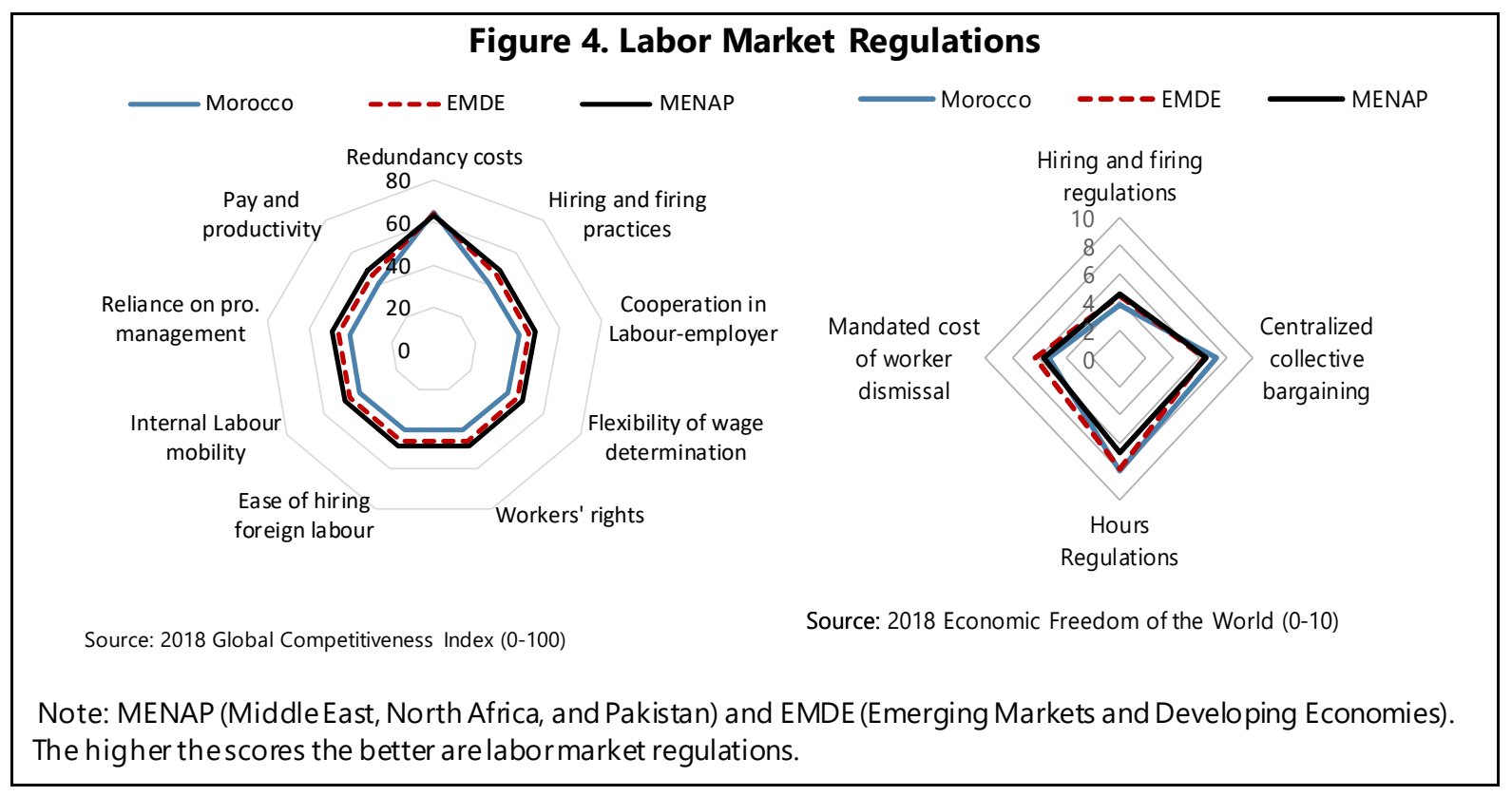

Only a minority of workers are covered by social security, which also contributes to greater informality in the labor market. The current social protection system is highly fragmented. It is composed of around 140 insurance or social assistance programs, ranging from universal transfers to mechanisms targeting specific population groups. Rationalizing these programs could help establish a more comprehensive unemployment insurance scheme (the current scheme provides replacement income for up to six months), helping to better protect workers and complementing other labor market reforms.

There are several weaknesses in workers' protection. According to a 2018 report by the $\mathrm{HCP},{ }^{9}$ one out of four workers doesn't have medical insurance and this share is even higher in urban areas (38 percent). Regarding the pension system, only one out of five workers has access to a pension system (about 31 percent in urban areas). Therefore, the challenge is to implement appropriate pro-growth PMRs and LMRs while ensuring that workers are better protected. While it might take less time to find a job in the informal sector than in the formal sector, a more supportive unemployment benefits scheme would give workers more time to choose the formal sector where wages and productivity are higher.

\section{The Informal Economy}

Informality is a key feature of the Moroccan economy. The High Commission for Planning has conducted three surveys of the informal economy in the last two decades (2000, 2007, and 2014). ${ }^{10}$ According to the 2014 survey results, the informal economy represented 11.5 percent of nonagricultural GDP, and the number of informal units increased at an average rate of 1.2 percent

20

${ }^{9} \mathrm{HCP}$ (2018). Note du Haut-Commissariat au Plan relative aux principales caractéristiques de la population active occupée en 2018.

${ }^{10}$ These surveys covered all but the agriculture sector for which specific surveys are designed. Other studies have found the contribution of the in formal economy to be larger in Morocco (AnnexIV). 
per year since 2007, reaching 1.68 million units in 2014, most of them (71 percent) concentrated in urban areas. Previous studies have shown that informality reflects the lack of access to education, excessive labor market regulations, and complex bureaucratic procedures among other factors. ${ }^{11}$

Labor market informality is close to $\mathbf{4 0}$ percent in the non-agricultural sector. Employment in the informal sector amounted to 2,376 million jobs in 2014, compared with 2,216 million in 2007 and 1,902 million in 1999. The share of informal sector employment in non-agricultural employment remains high but has declined slightly to 36.3 percent in 2014 up from 37.3 percent in 2007. At the same time, the informal sector is highly labor intensive, and investment is low and represented only 1 percent of the total investment in 2014.

The informal sector is dominated by small and micro units. The turnover of the sector reached MAD 410 billion in 2014, the equivalent of more than 50 percent of the nonagricultural GDP. Moreover, half of the informal units have an annual turnover lower than MAD 100000. In parallel, almost 75 percent of the informal units are composed by only one person, and less than 8 percent of those units have more than three employees.

The educational level of the heads of informal units and their managerial capacity are limited, therefore their productivity level is low compared to formal units. The 2014 survey highlighted that more than one third of the informal entrepreneurs had no education, while only 3.3 percent had a high degree. Also, organizational and managerial problems are the main difficulty preventing their development according to half of the informal units surveyed.

Informal goods are mainly consumed by households. Households constitute the informal sector's primary market with a share of 77.8 percent while sales to formal businesses, the public sector, and exports are insignificant. The informal sector does not have access to foreign markets to purchase goods or sell its products. Additionally, 70.9 percent of the inputs used for informal production come from the sector itself, while inputs from the formal sector remain limited.

\section{KEY CONSTRAINTS IN THE BUSINESS ENVIRONMENT}

Morocco has modernized its economy and significantly strengthened its business environment. Morocco's greater openness was accompanied by efforts to improve business procedures, providing better protection to private operators through the introduction of new laws aiming at improving investment conditions. Consequently, Morocco has been successful in attracting consistent flows of foreign capital. This progress has materialized in significant increases of Morocco's scores in the latest Doing Business and Global Competitiveness reports (Figure 5). For instance, the country gained 68 ranks in Doing Business between 2010 and 2019 (from 128th to 60th). Important efforts have been made to simplify administrative procedures (such as, customs transactions, property rights, and enterprise creation), and a new insolvency regime has been recently introduced.

A new wave of reforms would help to remove barriers to entry and promote a more competitive environment that promotes private sector-led growth. A survey of different

${ }^{11}$ See for instance Angel-Urdinola and Tan abe (2012). 
indicators shows that further progress is needed, including in the following areas: facilitation of SME access to finance and reduction of payment delays; reinforcement of anti-corruption measures; and enhancement of competition practices.

\section{A. Access to credit and payment delays}

Credit to SMEs is relatively high by regional standards, at about 16 percent of total credit, but it has been stagnant in recent years, and collateral requirements remain high. While 76 percent of large enterprises in the 2013 World Bank enterprise survey had a bank loan or a line of credit, this was the case for only 42 and 57 percent of small and medium enterprises, respectively. Furthermore, credit allocation tends to be biased toward the sectors where Morocco's largest corporates are involved (including the state-owned ones) at the expense of the tradable sectors (World Bank, 2018). IMF (2019) estimated that greater SME financial inclusion could help increase economic growth in Middle Eastern countries by about 0.5 percentage point annually.

In addition to their difficulties in accessing finance, payment delays continue to weigh on companies in Morocco. According to the payment survey by Coface, payment delays increased from 66 days in 2015 to 99 days in 2017 on average (the new regulatory framework aims at 60 days). The percentage of firms that faced delays greater than 120 days surged in 2017, at 42 percent instead of 13 percent in 2016, with delays of up to 158 days for very small enterprises. The government created an Observatory of payment delays to address this issue, which could rapidly improve business conditions for SMEs by easing their cash flow situations.

\section{B. Competition and Corruption}

Competition remains an important constraint to Morocco's growth potential. SMEs often find it difficult to access certain markets or sectors due to barriers to entry or the existence of monopolies or oligopolies favoring dominant positions (World Bank, 2018). Promoting market competition will be key to enhance private sector-led growth, and the reactivation of the Competition Council in 2018 should support progress in this area.

Corruption is most commonly cited by enterprises as one of the largest impediments to doing business in Morocco. Corruption is an important barrier to entry because it reduces competition and creates uncertainty for potential market entrants (Campos and others, 2010). According to the World Bank's 2013 Enterprise Survey, over 20 percent of enterprises indicate that it is the largest impediment to doing business in Morocco, compared to 7 percent in the MENA region. Reducing corruption vulnerabilities could contribute to lowering barriers to entry, foster private sector development and so enhance economic growth. 
Figure 5. Doing Business and Competitiveness

Doing Business Indicators

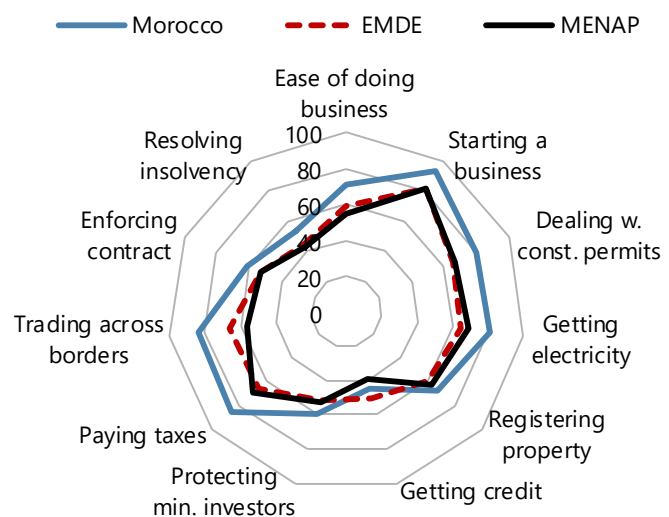

Source: World Bank's Doing Business Report (2018)

Business Regulations

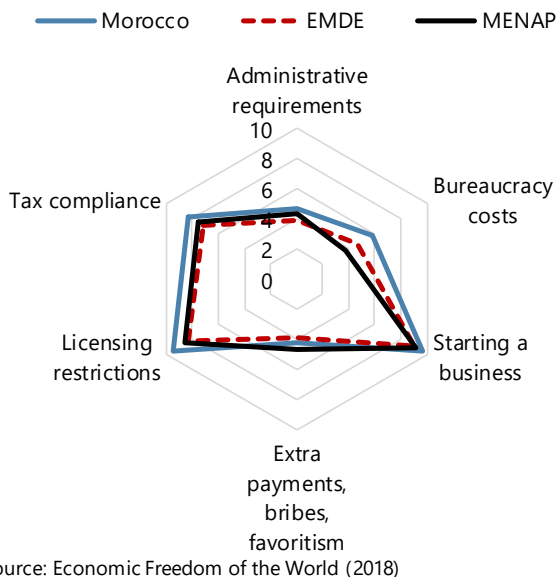

Credit to the Nonfinancial Private Sector over the Contribution of the Nonfinancial Sector to GDP (2014)

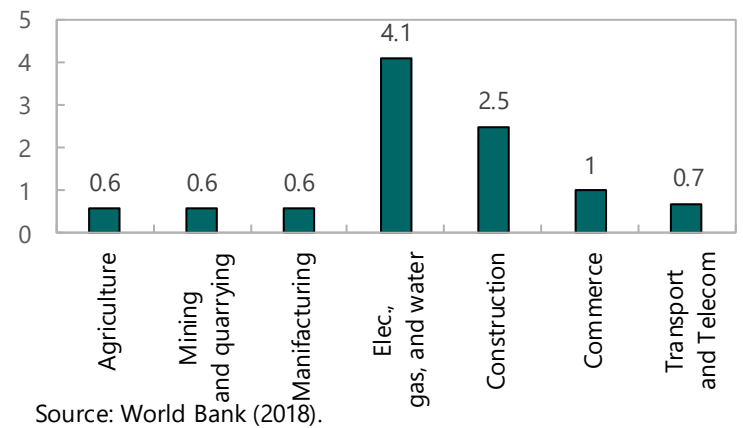

Global Competitiveness Indicators

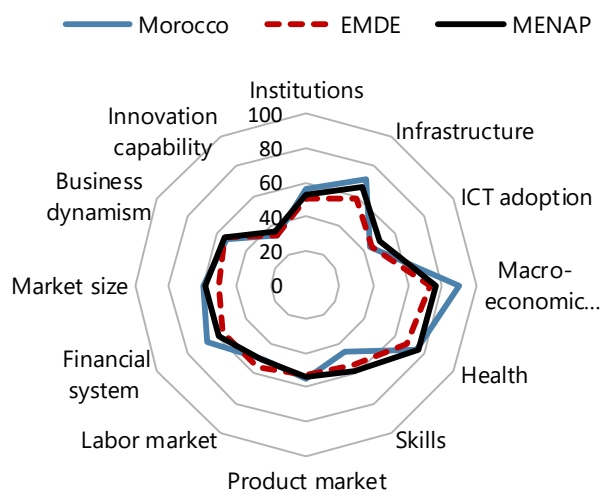

Source: World Economic Forum's Global Competitiveness Report

Ranking of the Top Business Environment Obstacles for Firms (Percent of firms, \%)

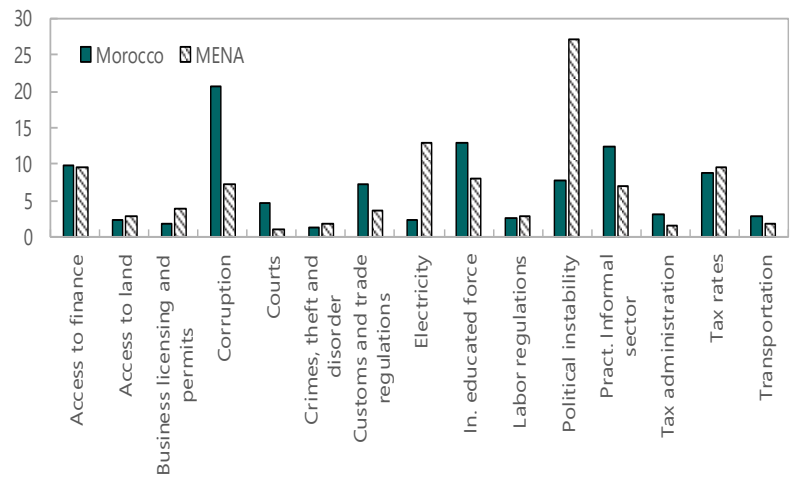

Source: Enterprise Survey (2013)

\section{Payment Delays Average Number of Days}

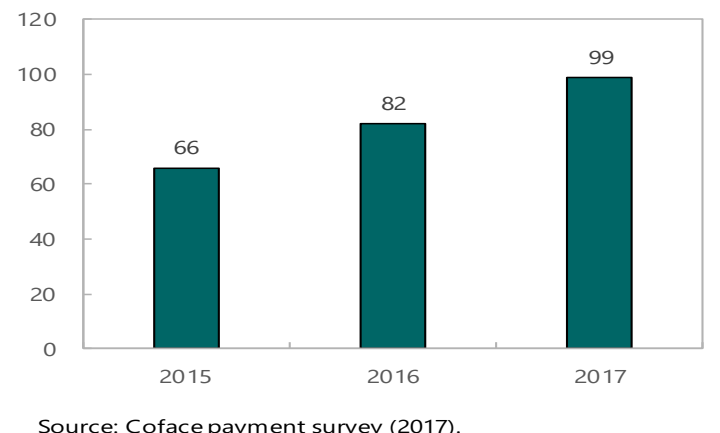


Table 1 summarizes key reforms in the areas described above that could help promote higher and job-rich growth in Morocco. The next section will analyze the reaction of output and unemployment to different reform scenarios in these areas. Our approach will allow us to assess the impact of reforms through two key variables, namely formal firms' hiring and entry costs ${ }^{12}$.

\begin{tabular}{|c|c|}
\hline \multicolumn{2}{|c|}{ Table 1. Selected Reform Priorities } \\
\hline $\begin{array}{l}\text { Reforms that could reduce formal firms' } \\
\text { entry costs include: }\end{array}$ & $\begin{array}{l}\text { Reforms that could reduce formal firms' } \\
\text { hiring costs include: }\end{array}$ \\
\hline Simplification of administrative procedures & Reduction of bureaucratic hiring costs \\
\hline Facilitation of SME access to finance & Better education and training \\
\hline Promotion of fair market competition & Easing of hiring and firing regulations \\
\hline Strengthening of anti-corruption measures & $\begin{array}{l}\text { Alignment of minimum wage with labor } \\
\text { productivity }\end{array}$ \\
\hline
\end{tabular}

\section{EMPIRICAL APPROACH AND MAIN FINDINGS}

\section{A. Key Features of the Model ${ }^{13}$}

A small open-economy dynamic general equilibrium model with informal product and labor markets is calibrated for Morocco. This model was developed by Anand and Khera (2016) and Munkacsi and Saxegaard (2017) and is applied based on quarterly data between 2000 and 2017. The household sector is standard; there is a representative infinitively-living household that maximizes the expected discounted lifetime utility of consumption. Regarding the production sector, a differentiation is made between a formal and an informal sector. Both formal and informal wholesale good producers produce an intermediate good through a Cobb-Douglas production function. Both pay not only for the cost of labor and capital, but also for hiring costs of newly hired workers. Due to endogenous entry, the number of retailers is not normalized to one, and the number of firms, in both the official and unofficial sectors, endogenously affects price markups.

Several rigidities affect the hiring of new workers and firms' market entry, and these rigidities are lower in the informal economy. As described in previous sections, hiring costs can reflect compliance with hiring regulations, training needs (to make up for insufficient worker education), or administrative costs (e.g., time spent on hiring). The hiring probability may also be affected by firing difficulties due to stringent employment protection legislations. Creating a new company is costly in terms of both money and time, and depends on existing barriers (e.g., access

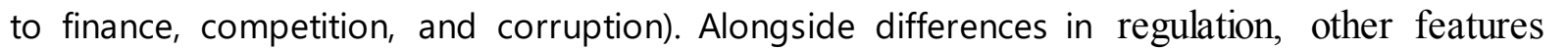
distinguish the formal and informal sectors: only the formal sector's labor income is taxed; the government can only purchase formal goods; investment is a function of formal goods only; labor

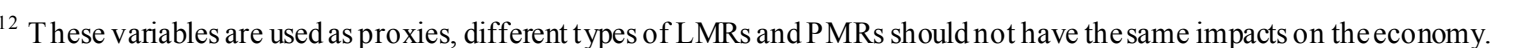

${ }^{13}$ As with any macroeconomic model, the analysis has limitations: as the model is restricted to two sectors, formal and informal goods, the direct an alysis of specific reforms (e.g. activating the competition council or easing hiring and firing regulations) is on ly ap proximated through its impact on broad aggregates.
} 
productivity in the informal sector is lower than in the formal sector; and formal goods are traded abroad, but informal goods are not.

\section{B. Main Findings}

Several simulations are performed to analyze the strategy for implementing labor and product market reform outcomes across three broad scenarios: uncoordinated/isolated decrease of formal firm's hiring costs and entry costs; a coordinated set of reforms where both hiring, and entry costs are reduced; and a sequential approach where one reform is introduced after the other. ${ }^{14}$

A first simulation focuses on the impact of isolated reforms that reduce formal firms' entry costs (by 10 percent) or formal firms' hiring costs (also by 10 percent). Taken in isolation, both reforms increase output and formal employment in the years following the reform with no short-term costs (Figure 6):

- Reducing formal firms' entry costs is very effective in boosting output as GDP increases by 1.4 percent after 5 years. However, the impact on unemployment is limited ( -0.5 percentage point). Reducing entry costs promotes competition, which leads to a reduction in price markups. Additionally, as demand for factors of production increase, real wages and households' wealth increase, resulting in higher consumption. The higher demand for capital also stimulates private investment. The limited effect on job creation could be explained by an increase in capital intensity given unchanged labor market regulations. Overall, this simulation shows that reforms that reduce firms' entry costs, while being growth-friendly, are not sufficient to significantly boost formal job creation.

- Reducing formal firms' hiring costs increases output by about 1 percent after 5 years; this is supported by higher investment as firms internalize lower production costs following labor market reforms. At the same time, despite a minor decline in formal wages, household consumption increases due to higher spending by new workers, thereby supporting total output. The most significant effect resides in the significant decline in unemployment (by 1.7 $\mathrm{pp}$ ), while the share of formal employment in total employment increases by $3.4 \mathrm{pp}$ after five years. Lower hiring costs encourage more efficient allocation of resources in the economy, including labor utilization. Importantly, while the short run impact of LMRs is often found to be small or even negative because of short-term adjustment costs (e.g. Cacciatore and others, 2012), these negative effects are not observed in the case of Morocco. ${ }^{15}$ This could be explained by the low activity rate and the high level of informal employment, as the increase in formal employment outpaces the number of potential layoffs. Therefore, reforms that lower hiring costs would be highly effective in boosting formal job creation in Morocco, both in the short and long run.

A second simulation assesses how combined reforms can increase growth and employment over the medium term and shows that there is no conflict or tradeoff between these reforms,

\footnotetext{
${ }^{14}$ The time lag between two reforms is assumed to be ten years to allow the model to converge before thein troduction of the second reform.

(口)
} 
but rather additivity of their impacts (Figure 6). A simultaneous 10 percent reduction in both $\square$ formal firms' entry costs and formal firms' hiring costs result in higher output, lower unemployment, and there is no tradeoff between the two reforms as all macroeconomic variables improve (compared to when these reforms are isolated). At the same time, formality increases significantly as both the number of formal firms and formal workers increases after 5 years. Therefore, the benefits of PMRs are higher when implemented in a more flexible labor market environment, thus leading to a steady and smooth transition towards the new steady state. While the issue of long-run substitutability versus complementarity between PMRs and LMRs remains empirically debated, our analysis supports that a broad reform package would be more beneficial as there is no conflict between the two sets of reforms, but rather an add itivity of the impacts. Therefore, accelerating labor market reforms to complement ongoing improvements to the business environment in Morocco could be particularly beneficial to optimize their effects in the current environment of subdued growth and high unemployment, especially among the youth. $\square$

\begin{tabular}{|c|c|c|c|}
\hline \multicolumn{4}{|c|}{$\begin{array}{l}\text { Table 2. Short-Term Effects (After } 5 \text { Years) of Structural Reforms on Selected } \\
\text { Macroeconomic Indicators (In Percentage Points) }\end{array}$} \\
\hline Reform Scenarios & $\begin{array}{c}\text { GDP } \\
\text { growth }\end{array}$ & Unemployment & $\begin{array}{c}\text { Formal } \\
\text { Employment }\end{array}$ \\
\hline 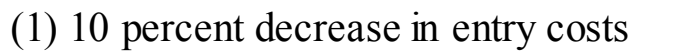 & $\square \square$ & $\square \|$ & $\square \square$ \\
\hline 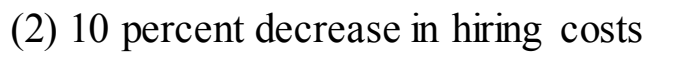 & $\square \mathrm{ll}$ & $\square \|$ & $\square \square$ \\
\hline \multirow{2}{*}{ 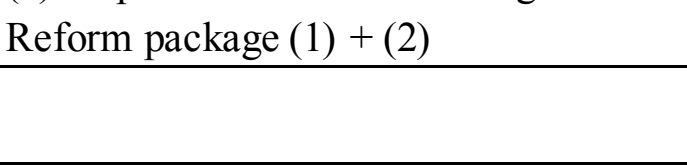 } & $\square \square$ & $\square \square$ & $\square \square$ \\
\hline & $\begin{array}{l}\text { Formal } \\
\text { Wage }\end{array}$ & $\begin{array}{l}\text { Consumption } \\
\text { \%GDP }\end{array}$ & $\begin{array}{l}\text { Inves tment } \\
\% \text { GDP }\end{array}$ \\
\hline 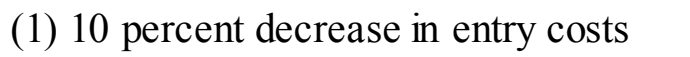 & $\square \mathrm{DI}$ & $\square \square$ & $\square \mathrm{IID}$ \\
\hline 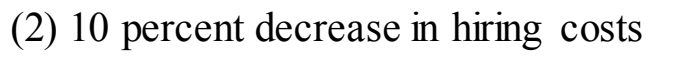 & एणा & $\square \square$ & $\square \square$ \\
\hline 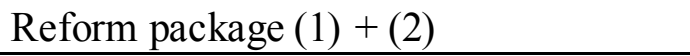 & $\square \|$ & $\square \square$ & $\square \square$ \\
\hline
\end{tabular}

$\square$

Finally, if it is decided that labor and product market reforms should be introduced sequentially (e.g., due to capacity or political economy constraints), a policy prioritization would be needed between reducing unemployment or boosting GDP more quickly (Figure 7). In this case, two simulations are performed: (i) starting with reforms that reduce firm's entry costs (S1), and (ii) starting first with reforms that reduce firms' hiring costs (S2). Under S1, output goes faster in the first step of the transition, and then converges gradually toward the new steady state. Under S2, unemployment falls more quickly and stays at lower levels for a longer time. On average, the growth gain under $\mathrm{S} 1$ relative to $\mathrm{S} 2$ is about $0.5 \mathrm{pp}$, while under $\mathrm{S} 2$, the unemployment rate is lower than under $\mathrm{S} 1$ by $0.6 \mathrm{pp}$ over the projection period. Therefore, each scenario has its own short-run advantages in terms of boosting output or job creation. In the case of Morocco, given the notable progress made in improving the business environment in recent years, and the urgency of promoting inclusive growth, prioritizing LMRs may be a preferable option to achieve the dual objective of boosting growth and reducing the unemployment rate.

Improving the unemployment insurance scheme could complement other structural reforms, but this would entail some costs. Given the political economy constraints associated with PMRs and LMRs, the government may consider introducing more generous unemployment insurance, especially to accompany the easing of hiring and firing regulations. Existing 
unemployment benefits do not provide workers with enough replacement income when they are unemployed (coverage lasts for only six months and does not exceed the minimum wage). However, reforms that increase unemployment benefits should be carefully designed and sequenced. In the following simulations, we test the impact of increasing unemployment benefits by 10 percent under different scenarios, alongside PMRs and LMRs discussed in the previous sections.

Choosing the appropriate timing for increasing the unemployment benefits as well as coordinating it well with PMRs and LMRs would help minimize its negative impact on growth and unemployment. We study two broad sets of policy packages: a first set of reforms where entry costs, hiring costs, and unemployment benefits are modified sequentially (one-byone); and a second set of reforms where two of the three shocks are combined followed, or preceded by the third shock.

- In all policy cases, raising unemployment benefits has a negative effect on output while unemployment increases significantly (Figure 8). It affects output through both consumption and investment. Whether financed by corporates or the government, it may increase layoffs and discourage investment. While higher benefits would raise consumption of unemployed workers (relative to the baseline), the potential increase in unemployment results in a decline of overall consumption because the benefits only make up for a fraction of the lost income for the newly unemployed. In terms of sequencing, starting with unemployment benefits increase has more damaging effects as GDP decreases by an average of 0.7 percent (if this reform is followed by a reduction in hiring costs) and 1 percent (if this reform is followed by a decrease in entry costs) over the projection period; unemployment increases on average by 1.9 and 2.3 percent, respectively (Table 3). This means that if unemployed benefits need be increased to accompany other reforms, this should be done after the introduction of other PMRs and LMRs. The sequence with the highest positive impact on GDP is: 1 . reduce entry costs, 2 . reduce hiring costs, and 3. increase unemployment benefits. The sequence with the highest reduction in unemployment starts with reducing hiring costs.

- When reforms are both sequenced and combined (Figure 9), the findings are consistent with our previous conclusions, namely, that it's preferable to raise unemployment benefits after the other reforms have taken place; this is true whether the reform is introduced alone or combined with PMRs or LMRs. The best-case scenario appears to be reducing first both hiring and entry costs, and then increasing unemployment benefits. Such a policy package would result in a significant increase in GDP, while unemployment would also be reduced by a large amount. As discussed earlier, combining these two reforms increases both private consumption and investment in the context of more favorable business conditions and improved labor market functioning. The increase in unemployment benefits brings back output to a lower level, which is still higher than in the initial steady state with no reforms. If the government was to start with the unemployment benefits reform, output would decrease by an average of 2.5 percent, while unemployment would increase by 4 percentage points. 
Table 3: Output and employment effects of different policy sequences of LMRs, PMRs, and increasing unemployment benefits

\begin{tabular}{|c|cc|cc|}
\hline Reform Scenarios & \multicolumn{2}{|c|}{ GDP growth (pp) } & \multicolumn{2}{c|}{ Unemployment (pp) } \\
& Average & Std. dev & Average & Std. dev \\
\hline 1UB_2HC_3EC & -0.99 & 1.59 & 1.89 & 1.24 \\
1UB_2EC_3HC & -0.69 & 1.58 & 2.27 & 1.26 \\
1HC_2UB_3EC & 0.53 & 1.00 & -0.07 & 1.28 \\
1HC_2EC_3UB & 2.30 & 1.14 & -1.59 & 1.20 \\
1EC_2HC_3UB & 2.60 & 0.97 & -1.21 & 1.20 \\
1EC_2UB_3HC & 1.12 & 0.85 & 1.05 & 1.30 \\
\hline 1UB_1EC_2HC & 0.48 & 0.78 & 1.54 & 1.01 \\
1HC_1EC_2UB & 2.56 & 0.99 & -1.28 & 1.32 \\
1UB_1HC_2EC & 0.01 & 1.14 & 0.99 & 0.58 \\
1UB_2EC_2HC & -2.19 & 0.48 & 3.95 & 0.61 \\
1HC_2EC_2UB & 1.38 & 0.39 & -0.79 & 1.04 \\
1EC_2HC_2UB & 1.83 & 0.47 & -0.22 & 0.61 \\
\hline
\end{tabular}

Note: $U B=10 \%$ increase in unemployment ben efits; $\mathrm{EC}=10$ percent decrease in entry costs; $\mathrm{HC}=10 \%$ decrease in hiring costs. 1, 2, and 3 indicate that a particular reform is carried out as first, second, or third. The packages with 3 sequenced reforms take 30 years, while the packages with both sequenced and comb ined reforms take 20 years.

\section{CONCLUSION}

The analysis suggests that the benefits of well-designed structural reforms are likely to be considerable over the medium term in Morocco. Reforms aimed at reducing hiring costs (e.g., more flexible contracts, minimum wage aligned with labor productivity, better training to reduce skill mismatches) could substantially increase output and employment over the medium term. Similarly, policy actions that reduce barriers to entry (e.g., simplifying administrative procedures, curbing corruption, enhancing SME access to finance) would also increase output, but with limited effects on formal employment. Importantly, the results provide robust evidence that a reform package combining both a reduction in hiring costs and entry costs would have a greater impact with a reduction of unemployment by 2 percentage points and an increase in GDP by about 2.5 points after 5 years. If reforms need to be sequenced, a policy choice would need to be made in the short run, considering that starting with LMRs would be more effective in reducing unemployment, while starting with PMRs would boost output more rapidly.

Compounding the impact of recent efforts to improve the business environment, ambitious labor market reforms would help promote more job-rich growth in Morocco. Morocco has made considerable progress in improving its business environment in recent years, but a new wave of reforms (access to finance, market competition) would further support private sector-led growth. At the same time, the above analysis shows that introducing reforms that lower formal firms' hiring costs will be key to improve labor market functioning and create the conditions for stronger job creation. Easing restrictions on hiring and firing would make the labor market more flexible and help reduce unemployment. Relaxing restrictions on the use of fixed-term contracts, 
especially for the youth and new job seekers, and implementing more efficient dismissal procedures while strengthening social and unemployment safety nets, would make it easier to create the needed formal jobs. Finally, both the education and the vocational training systems need to be upgraded to reduce skill mismatches in the labor market as hiring costs are higher in part due to insufficient human capital.

To better protect workers and facilitate the dialogue with social partners, PMRs and LMRs could be accompanied with a reform of the unemployment insurance scheme. The existing system is inadequate and does not protect unemployed workers well enough (i.e., both the coverage and the amount are low). At the same time, increasing unemployment benefits comes with some additional costs. These costs could be minimized by coordinating and sequencing the reforms appropriately. The simulations have shown that in any case, unemployment benefits should be increased after PMRs and LMRs have been implemented. Offering better unemployment insurance will also reduce incentives for unemployed workers to join the informal sector. 
Figure 6. Macroeconomic Effects of Single/Joint Labor and Product Market Reforms in 10 Years (10 percent decrease in entry costs and/or hiring costs)

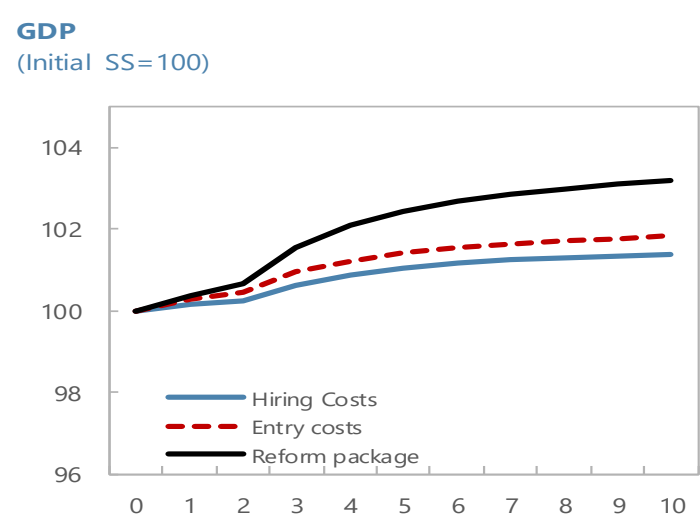

Unemployment
(Initial SS =100)

Formal employment

(Initial SS $=100$ )
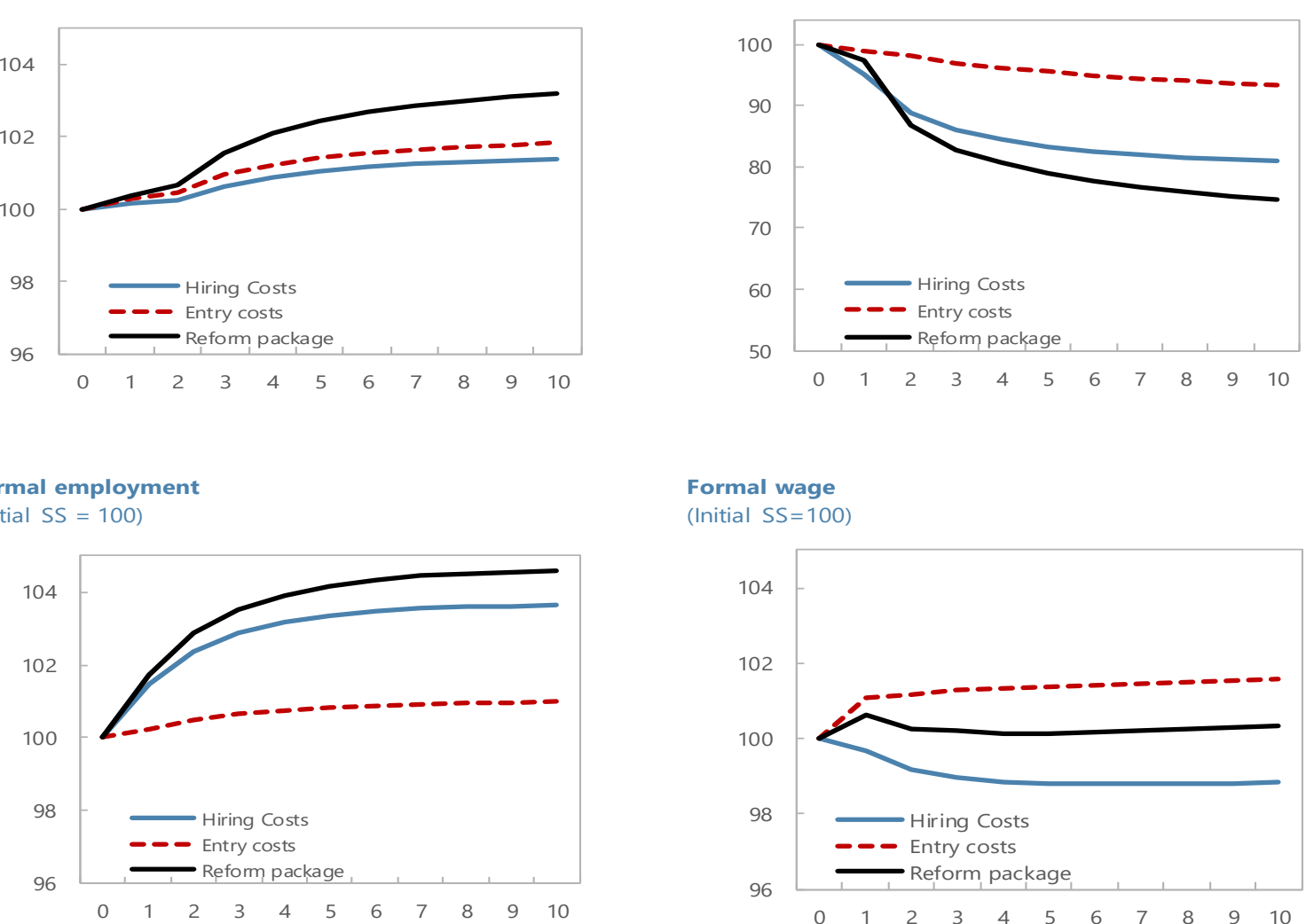

Formal wage

(Initial SS=100)

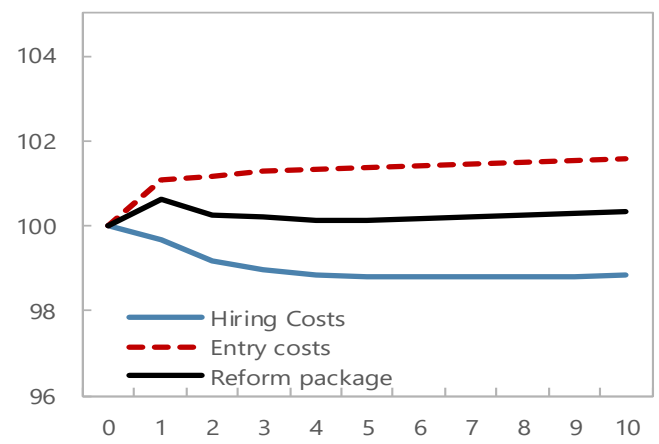

Household consumption

(Initial SS=100)

Investment

(Initial SS=100)
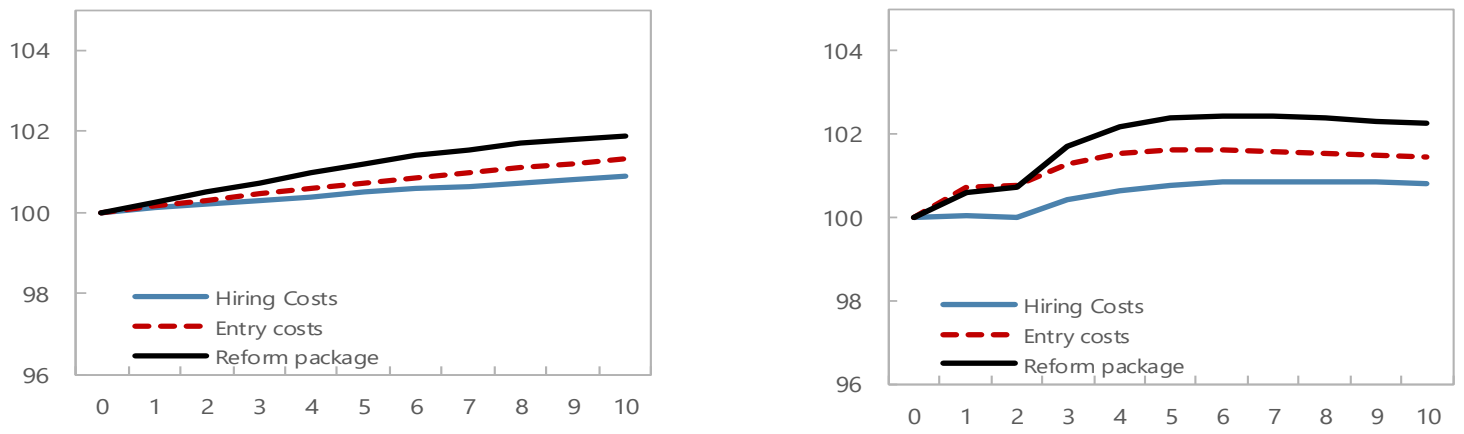

Note: Initial SS=Initial steady state 
Figure 7. Macroeconomic Effects of Labor and Product Market Reform Sequencing in 20 years ( $10 \%$ decrease in entry costs first/hiring costs first)

GDP

(Intial SS $=100$ )

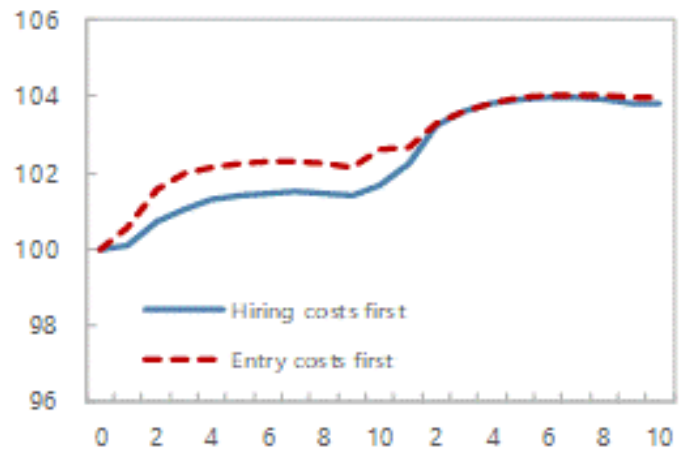

Formal employment

(Initial SS=100)

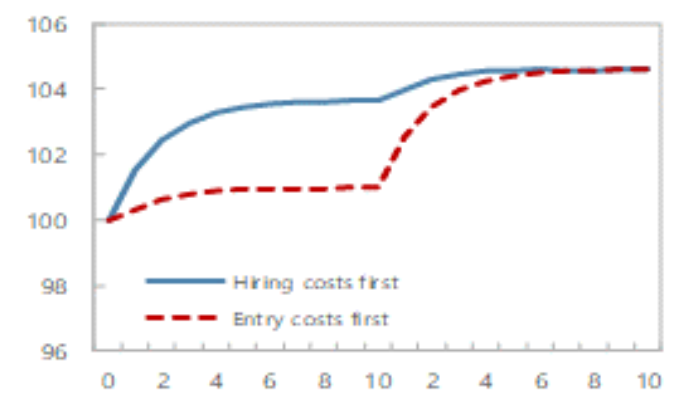

Household consumption

(nitial SS=100)

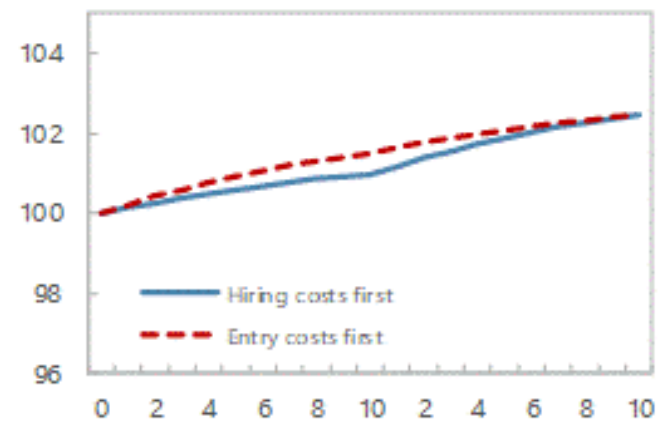

Unemployment

(Initial SS=100)

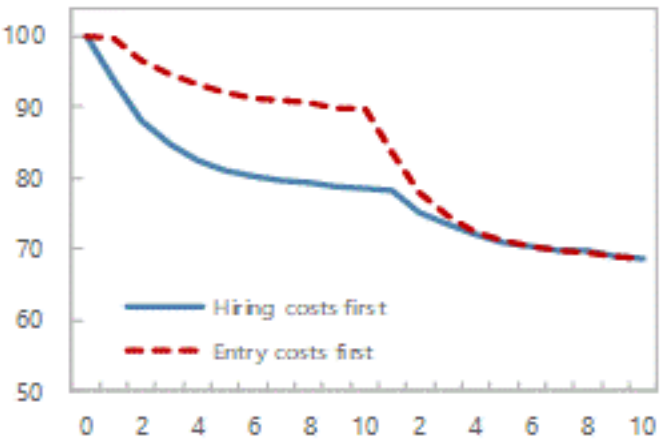

Formal wage

(Initial SS=100)

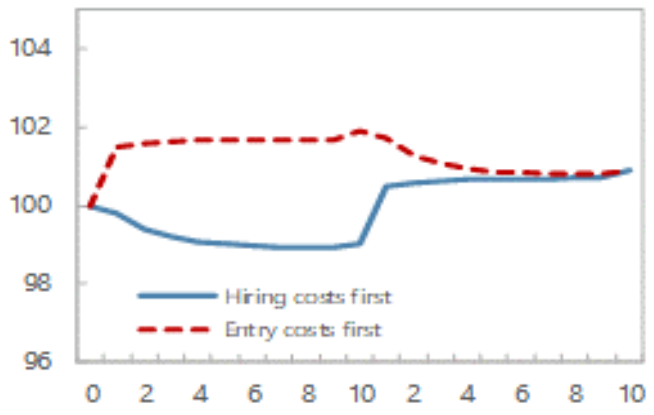

Investment

(Initial SS=100)

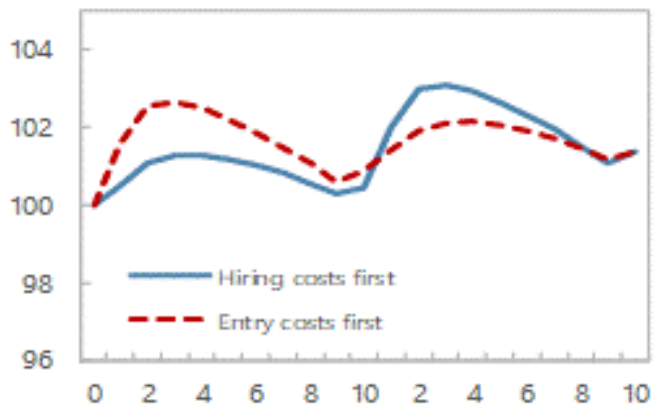


Figure 8. Output and employment effects of reform sequencing (10\% decrease in entry costs and hiring costs, and $10 \%$ increase in unemployment benefits)

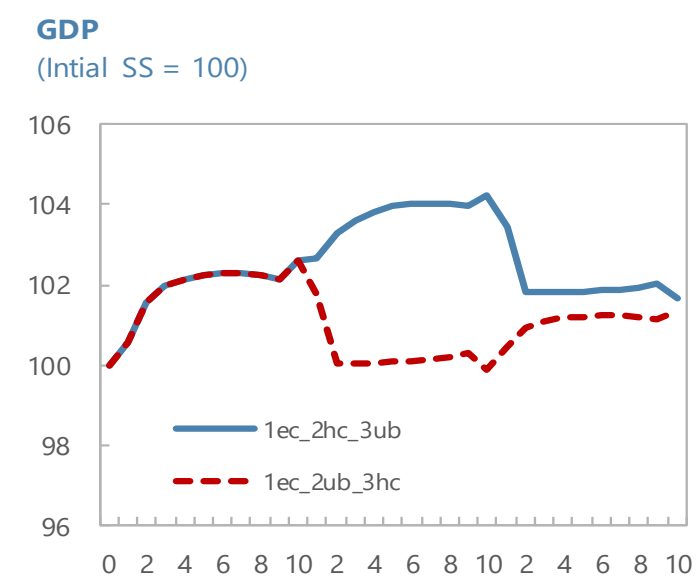

Unemployment

(Initial SS=100)
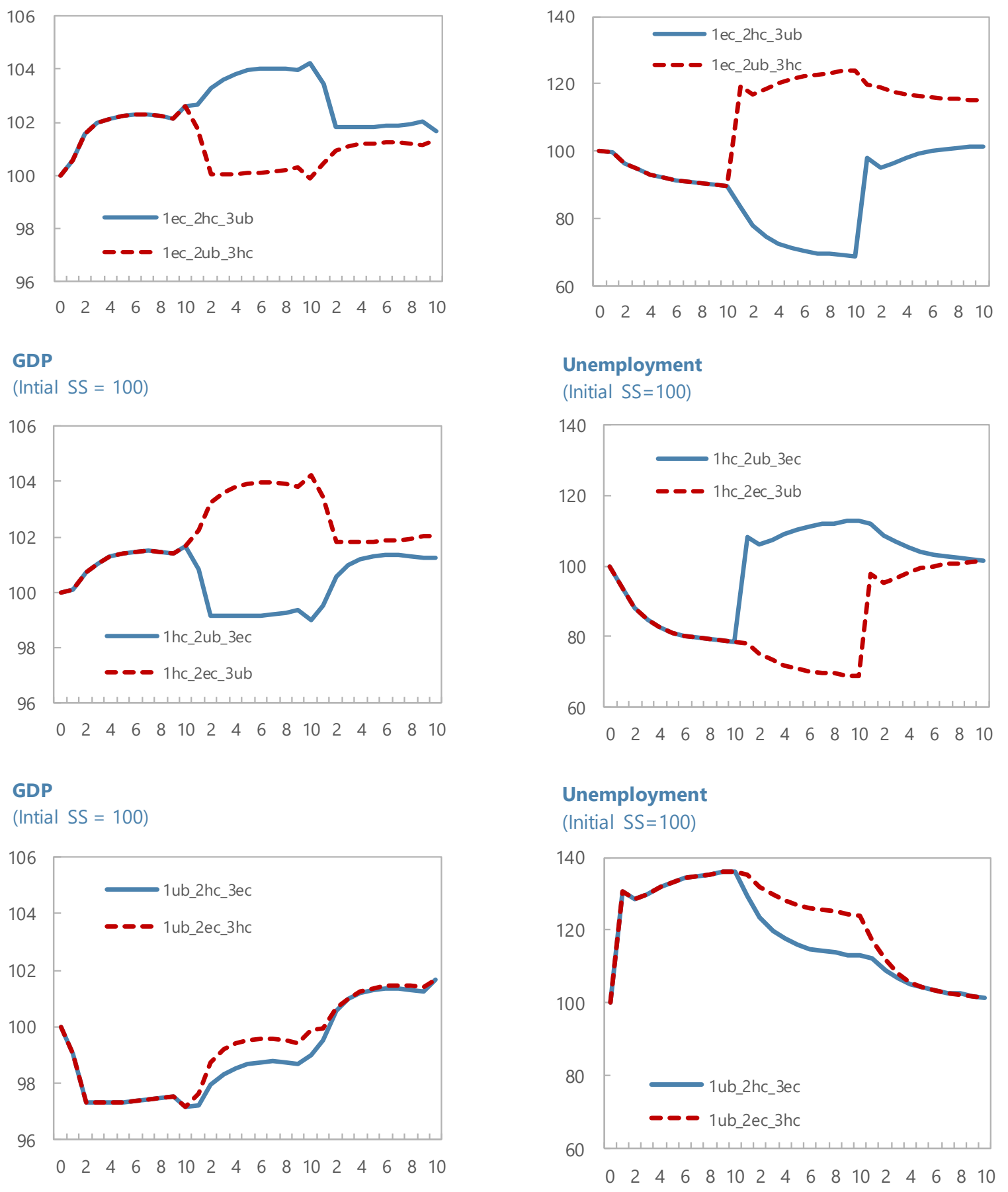
Figure 9. Output and employment effects of reform packaging and sequencing (10\%

decrease in entry costs and hiring costs, and 10\% increase in unemployment benefits)
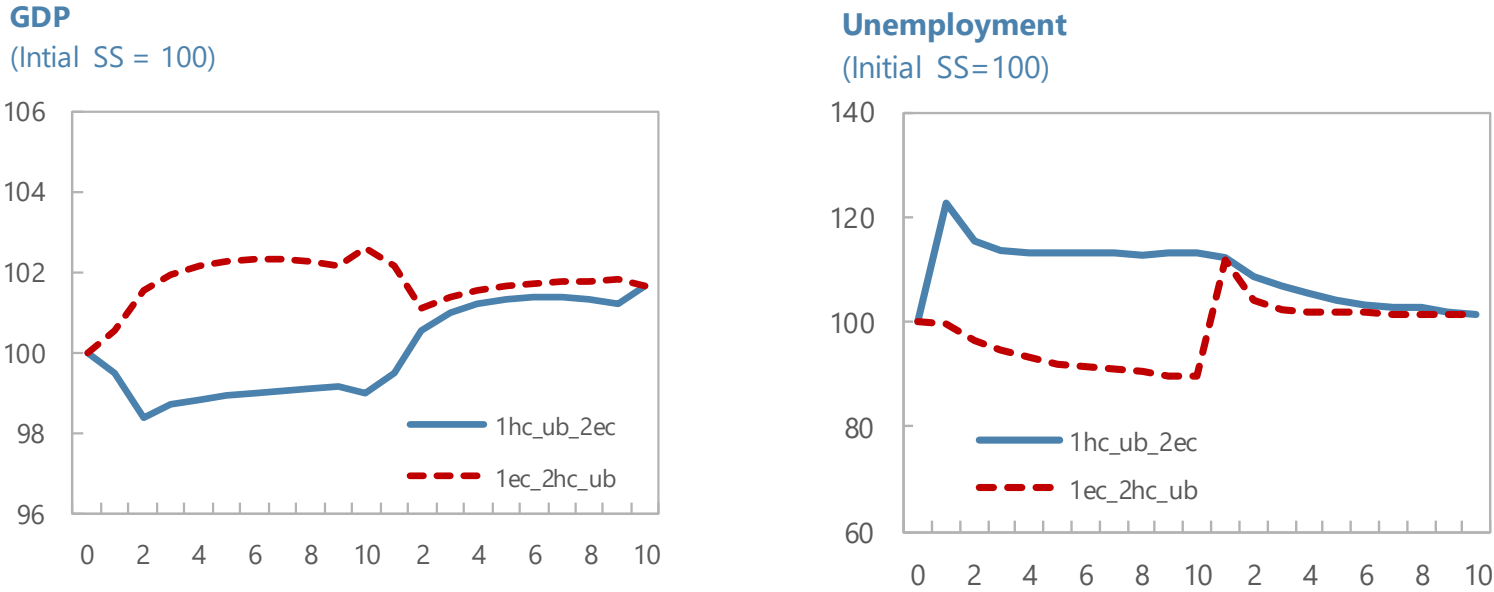

GDP

$($ Intial SS $=100)$

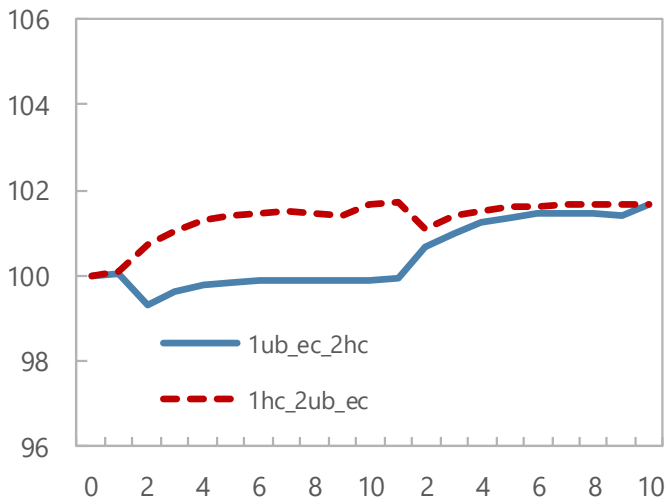

Unemployment

(Initial SS=100)

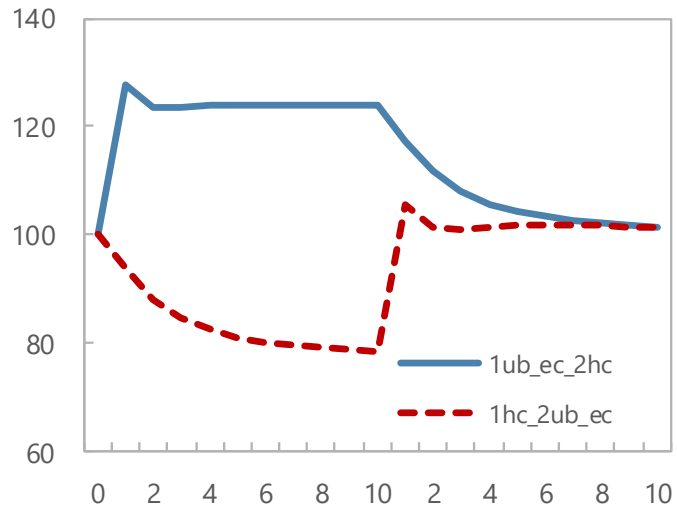

GDP

(Intial SS $=100)$

Unemployment

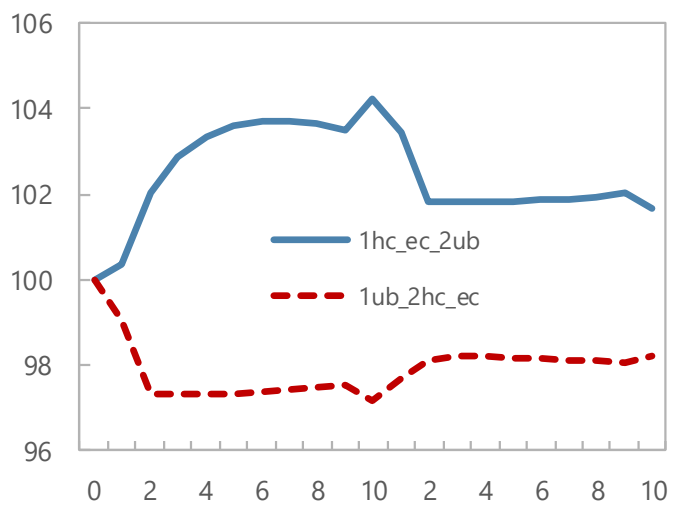

(Initial SS=100)

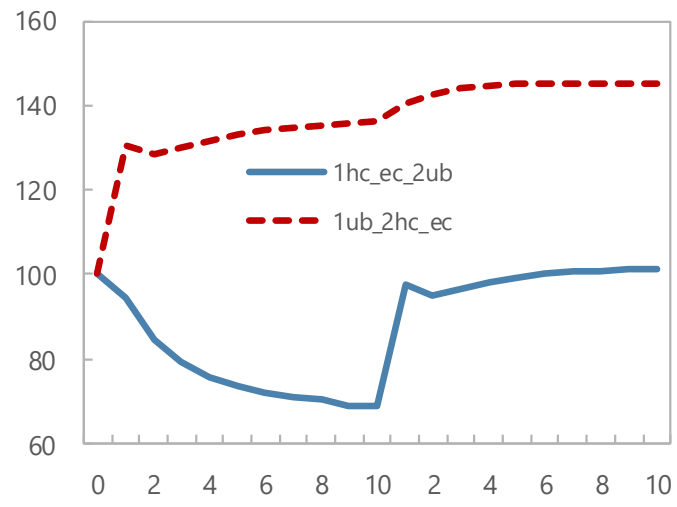




\section{REFERENCES}

Anand, R., \& Khera, P. (2016). Macroeconomic Impact of Product and Labor Market Reform on Informality and Unemployment in India. IMF Working Paper WP/16/47 (Washington: International Monetary Fund).

Angel-Urdinola, D., \& Tanabe, K. (2012). Micro-Determinants of Informal Employment in the MiddleEast and North Africa Region. World Bank SP Discussion Paper No. 12/01 (Washington: World Bank).

Bassanini, A., Nunziata, L., \& Venn , D. (2009). Job Protection Legislation and Productivity Growth in OECD countries. Economic Policy, Volume 24, Issue 58, 349-402.

Bordon, A., Ebeke, C., \& Shirono, K. (2016). When Do Structural Reforms Work? On the Role of the Business Cycle and Macroeconomic Policies. IMF Working Paper WP/16/62 (Washington: International Monetary Fund).

Boudarbat, B., \& Egel, D. (2014). The Effectiveness of Vocational Training in Morocco: Quasi Experimental Evidence. Regional and Sectoral Economic Studies vol. 14, issue 2.

Bouis, R., \& Duval, R. (2011). Raising Potential Growth After the Crisis: A Quantitative Assessment of the Potential Gains from Various Structural Reforms in the OECD Area and Beyond. OECD Economics Department Working Papers 835.

Cacciatore, M., Duval, R., \& Fiori, G. (2012). Short-Term Gain or Pain? A DSGE Model-Based Analysis of the Short-Term Effects of Structural Reforms in Labour and Product Markets. OECD Economics Department Working Papers, No. 948.

Campos, N., Estrin, S., \& Proto, E. (2010). Corruption as a Barrier to Entry: Theory and Evidence. CEPR Discussion Paper 8061.

Dabla-Norris, E., Ho, G., \& Kyobe, A. (2016). Structural Reforms and Productivity Growth in Emerging Market and Developing Economies. IMF Working Paper WP/16/15 (Washington: International Monetary Fund).

Egert, B. (2017). The Quantification of Structural Reforms. OECD Economics Department Working Papers, 54.

Elgin, C., \& Oztunali, O. (2012). Shadow Economies Around the World: Model Based Estimates.

Bogazici University Working Paper 2012/05.

International Monetary Fund. (2011). Labor Market Reforms and unemployment Outcomes. IMF Country Report No. 11/341 (Washington).

International Monetary Fund. (2013). Morocco: Selected Issues. IMF Country Report No. 13/110 (Washington). 
International Monetary Fund. (2015). The New Normal: A Sector-Level Perspective on Growth and

Productivity Trends in advanced economies. IMF Staff Discussion Note SDN/15/03 (Washington). International Monetary Fund. (2016). Morocco: Selected Issues. IMF Country Report No. 16/36

(Washington).

International Monetary Fund. (2017). Macro-Structural Policies and Income Inequality in Low-Income

Developing Countries. IMF Staff Discussion Note SDN/17/01 (Washington).

International Monetary Fund. (2018). Morocco: Selected Issues. IMF Country Report No. 18/76

(Washington).

International Monetary Fund. (2019). Financial Inclusion of Small and Medium-Sized Enterprises in the Middle East and Central Asia. IMF Departmental Paper No. 19/02 (Washington).

Lahcen, M. (2014). "DSGE models for developing economies: an application to Morocco," MPRA

Paper 63404, University Library of Munich, Germany.

Medina, L., \& Schneider, F. (2018). Shadow Economies Around the World: What Did We Learn Over the Last 20 Years. IMF Working Paper WP/18/17.

Munkacsi, Z., \& Saxegaard, M. (2017). Structural Reform Packages, Sequencing, and the Informal

Economy. IMF Working Paper No. 17/125 (Washington: International Monetary Fund).

Muravyev, A. (2014). Employment Protection Legislation in Transition and Emerging Markets. IZA

World of Labor, No 63.

Schneider, F. (2018). The Shadow Economy and Work in the Shadow: What do We (Not) Know? IZA

Discussion Paper Series DP No. 6423.

Singh, A., Jain-Chandra, S., \& Mohommad, A. (2012). Inclusive Growth, Institutions, and the

Underground Economy. IMF Working Paper WP/12/47 (Washington: International Monetary Fund).

World Bank. (2018). Morocco-Systematic Country Diagnostic. (Washington). 


\section{APPENDICES}

\section{Annex I. Structure of the Model}

\section{Representative household utility function}

A representative infinitely living household with perfect foresight consumes over time a bundle of formal, informal, and foreign goods. It maximizes expected discounted lifetime utility of consumption $\left(\square \square E_{\square} \sum_{t=\square}^{\infty} \beta^{t} \zeta_{C t} U \mathbb{C}_{t} \square\right.$ ), where the contemporaneous utility is given by $U \mathbb{C}_{t}=\square-h c \ln \mathbb{C}_{t}-C_{t-\square}\left[. \beta\right.$ is the discount factor, $\zeta_{C t}$ is the preference shock and $h c \in \square[\|$ is the external consumption habit parameter. In turn, the aggregate consumption bundle $C_{t}$ consists of home-produced goods $C_{H t}$ and foreign-produced (imported) goods $C_{f(t}$, $C_{t}=\left[\alpha^{\frac{\bar{\eta}}{\eta}} C_{H t}^{\frac{\eta-\square}{\eta}}+\square-\alpha \square^{\frac{\square}{\eta}} C_{f t}^{\frac{\eta-\square}{\eta}}\right]^{\frac{\eta}{\eta-\square}}$ where $\alpha \in \square \square$ and $\eta>\square$ is the elasticity of substitution between home and foreign produced goods. In turn, the home consumption $C_{H t}$ is also a composite of goods produced in the formal sector $C_{F t}$ and goods produced in the informal sector $C_{I t t}$ : $C_{H t}=\left[\omega^{\frac{\square}{\mu}} C_{F t}^{\frac{\mu-\square}{\mu}}+\square-\omega \square C_{I t t}^{\frac{\mu-\square}{\mu}}\right]^{\frac{\mu}{\mu-\square}}$, where $\omega \in \square \square \amalg$ represents the weight of formal sector goods in the basket, and $\mu>\square$ is the elasticity of substitution between sectoral goods.

\section{Household budget constraint}

The household earns labor income from working in the formal sector $\left(L_{F t}\right)$ or in the informal sector $\left(L_{I t t}\right)$, or it receives social benefits $W U_{t}$, which is an exogenous shock, if it is unemployed. $W F_{t}$ and 
$W I_{t}$ are the sectoral real wages; although only the formal sector's wage is subject to income $\tau_{\text {Femployeet }}$ which is an exogenous variable. $Y_{H P t}$ denotes home production.

The household's income also includes profits from wholesaler and retailer firms, denoted by W and R, respectively. The number of retailer firms is endogenous, while the number of wholesaler firms is normalized to one. The household pays for the entry costs (entry $y_{F t}$ and entry $y_{I t}$ ) of new firms $N_{F t}^{E}$ and $N_{I \not t}^{E}$.

The laws of motion for the retail firms are $\begin{aligned} & N_{F t}=\square-\delta_{F t} \llbracket N_{F t-\square}+N_{F t}^{E} \sqsubset \\ & \\ & N_{I I t}=\square-\delta_{I t} \llbracket N_{I t-\square}+N_{I t}^{E} \square\end{aligned}$ with sectoral bankruptcy rates $\delta_{F}$ and $\delta_{I}$.

Savings can be in the form of foreign bonds $B_{t}$ or in-home bonds $D_{t}$ which trade in complete markets. The household also pays a lump sum tax. Thus, the household budget constraint can be expressed as:

$$
\begin{aligned}
& \mathbb{Z}-\tau_{\text {Femployee } t}\left[W F_{t} L_{F t}+W I_{t} L_{I I t}+W U_{t} U_{t}+Y_{H P t}\right. \\
& +N_{F t t} \operatorname{Prof}_{F t}^{R}+N_{I I t} \operatorname{Prof}_{I t t}^{R}+\operatorname{Prof}_{F t}^{W}+\operatorname{Prof}_{I t t}^{W}-N_{F t}^{E} \text { entry }_{F t}-N_{I t}^{E} \text { entry }_{I t t} \\
& +D E P_{t} \frac{\square+i_{t-\square}^{\mathfrak{a}}}{\pi_{t}} R E R_{t-\square} B_{t-\square}+\frac{\square+i_{t-\square}}{\pi_{t}} D_{t-t}-R E R_{t} B_{t}-D_{t}= \\
& C_{t}+\operatorname{Tax}
\end{aligned}
$$

where $R E R_{t}$ is the real exchange rate and $D E P_{t}$ is the depreciation rate of the nominal exchange rate, $i_{t}$ is the nominal interest rate on home bonds, $i_{t}^{a}$ is the nominal interest rate on foreign bonds, which depends on the exogenous foreign interest rate, on the one hand, and on an interest rate premium related to the relative amount of foreign debt holdings, on the other hand, following Schmitt-Grohe and Uribe (2003). 


\section{Wholesale good firms}

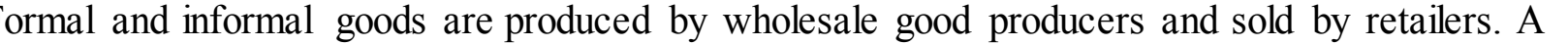

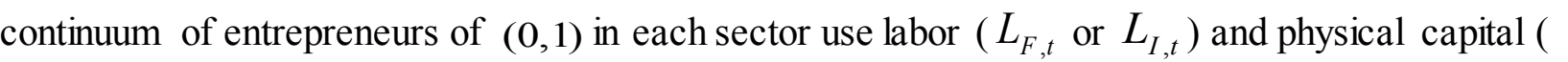

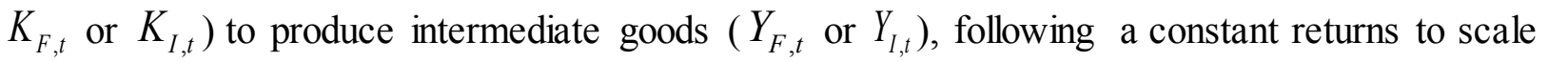

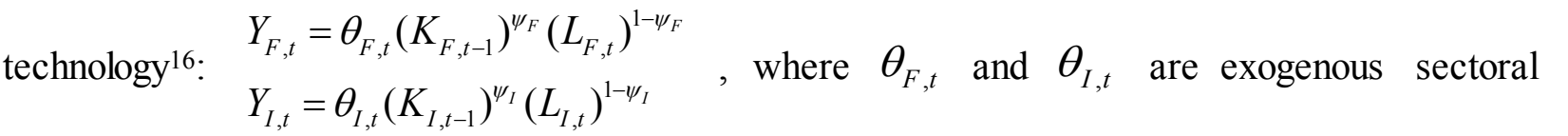

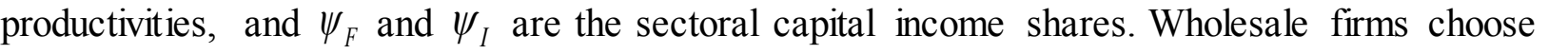

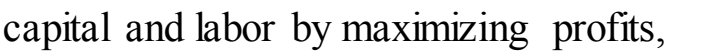

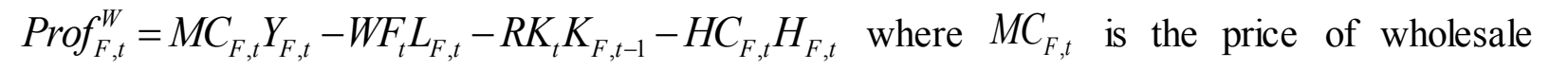

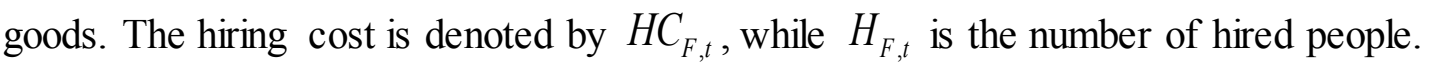

\section{Retailer good producers}

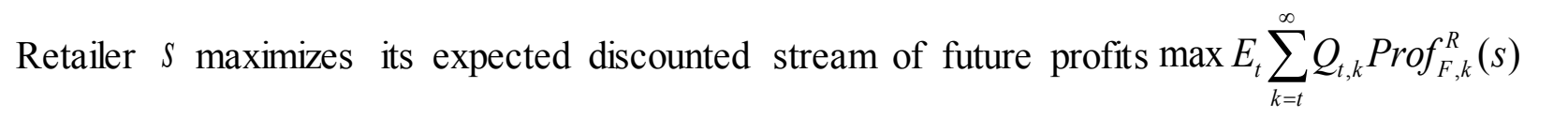

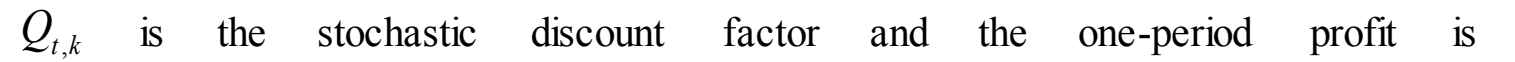

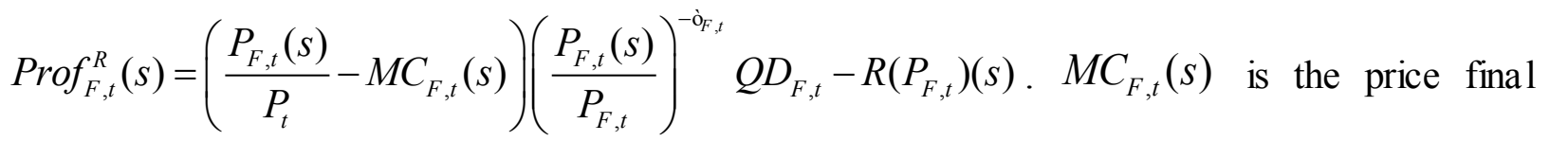

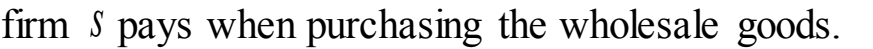

(1)

${ }^{16}$ Because in equilibrium all $i \in \square \mathbb{\|}$ intermediate firms follow the same optimization process, for the sake of simplicity we disregard the symboli when describing their optimization in most of this section.

CInternational Monetary Fund. Not for Redistribution 


\section{Investment and capital goods}

The capital producer owns physical capital, and, by investing, produces new physical capital. Investment is subject to a capital adjustment cost. This set-up follows that of Bernanke and others (1999). The capital producer invests such that its profit is maximized:

$$
\square \square Q_{t}\left\{\frac{P_{I N V t}}{P_{t}} I_{t}-\frac{\phi_{I N V}}{\square}\left(\frac{\frac{P_{I N V t}}{P_{t}} I_{t}}{K_{t-\square}}-\delta\right) K_{t-\square}-\frac{P_{I N V t}}{P_{t}} I_{t}\right\}
$$

where $Q_{t}$ is the price of physical capital.

The capital law of motion is standard, except that the price of investment is not equal to the general economy-wide price level because only goods produced in the formal sector can be used for investment:

$$
K_{t}=\square-\delta K_{t-\square}+\frac{P_{I N V t}}{P_{t}} I_{t}-\frac{\phi_{I N V}}{\square}\left(\frac{\frac{P_{I N V t t}}{P_{t}} I_{t}}{K_{t-\square}}-\delta\right) K_{t-\square}
$$

Aggregate investment is a composite of home produced and imported goods: $I_{t}=\left[\alpha^{\frac{\square}{\eta}} I_{H t}^{\frac{\eta-\square}{\eta}}+\square-\alpha \stackrel{\square}{\square} I_{f \downarrow t}^{\frac{\eta-\square}{\eta}}\right]^{\frac{\eta}{\eta-\square}}$

\section{Labor market dynamics}

The labor force is fixed at 1 , so that the unemployment rate $U N E M P_{t}$ is 1 minus formal and informal employment $L_{t}, \begin{aligned} & L_{F t}+L_{I t t}=L_{t} \\ & U_{t}=\square-L_{t}\end{aligned}$. Employment in each sector follows a law of motion of the type $L_{F t}=\square-\operatorname{probf}_{F t} L_{F t-\square}+H_{F t}$. At the beginning of period $t L_{F t-\square}$ people are employed. Then, at 
the beginning of period $t \quad \operatorname{probf}_{F t} L_{F t-\square}$ people are fired, where the exogenous firing probability is $\operatorname{probf}_{F t t}$. During period $t$, firms hire new workers. After firing and hiring is over, the end of period $t$ employment will be $L_{F t}$, which is also the level of employment at the beginning of period $t+\sqsubset$.

Hiring cost is a function of hiring probability: $H C_{F t}=\beta_{H C F t}\left(\operatorname{probh}_{F t}\right)^{\alpha_{H C F}}$, where the hiring probability is $\operatorname{probh}_{F(t)}=\frac{H_{F t}}{U_{t-\square}+p r o b f_{F I t} L_{F t-\square}+\operatorname{probf}_{I t t} L_{I t-\square}}$. Thus, the probability of hiring depends on the number of hired people $H_{F t}$ (the higher the number of hired people, the higher the probability of hiring) and on the number of people - potentially - available to hire. We assume that not only those who were unemployed at the beginning of period $t$ can be hired, but also those who have just lost their jobs in any of the sectors. The exogenous term $\beta_{H C F t}$ represents the per capita hiring cost, and this is the labor market deregulation variable, too. Finally, $\alpha_{H C F}$ is the elasticity of hiring cost with respect to the hiring probability.

\section{Wage bargaining}

Workers and firms bargain over real wages, a Nash bargaining process that can be proxied by a weighted maximization of the relative benefits to firms and workers, with the weights being the exogenously determined bargaining power of workers:

$$
\begin{aligned}
& \square \square\left(V_{t}^{F}-V_{t}^{U}\right)^{\lambda_{F I}}\left(J_{t}^{F}\right)^{\square \lambda_{F I}} \text {, where } \lambda_{F I} \text { is the bargaining power in the formal sector, } V_{t}^{F} \text { is the value } \\
& \square \square\left(V_{t}^{I}-V_{t}^{U}\right)^{\lambda_{I I}}\left(J_{t}^{I}\right)^{\square \lambda_{I I}}
\end{aligned}
$$

function of workers in the formal sector, $V_{t}^{I}$ is the value function of workers in the informal sector, 
$V_{t}^{U}$ is the value function of the unemployed, a $J_{t}^{S}$ is the value function of firms in sector $\mathrm{S}$ (formal or informal).

\section{Trade}

Exports $Q X_{t}$ respond to the relative price of exports with elasticity ${ }_{\text {VATHETAX }}$. $Q X_{t}=\frac{\text { PXPstar }_{t}}{\text { alphax }_{t}} \square^{\text {VATHETAX }}$. In turn, imports $Q M_{t}$ are the sum of imported consumer goods $C f_{t}$ , imported investment goods If and imported government consumption goods $G f \square$ $Q M_{t}=\mathbb{C} f_{t}+I f_{t}+G f \square$

\section{Fiscal policy}

The government collects labor taxes from the formal sector $\left(\tau_{\text {Femployee,t }}\right) W F_{t} L_{F, t}$ and a lump sum tax $\operatorname{Tax}_{t}$ to fund Government spending $\frac{P_{F(t}}{P_{t}} G_{t}$ and unemployment insurance $W U_{t} U_{t}$, managing public

debt issued in domestic currency Debt to smooth temporary revenue and spending fluctuations.

$$
\begin{aligned}
& \frac{P_{F, t}}{P_{t}} G_{t}+W U_{t} U_{t}+\frac{1+i_{t-1}}{P I E_{t}} * \operatorname{Debt}_{t-1}= \\
& \operatorname{Debt}_{t}+\operatorname{Tax}_{t}+\left(\tau_{\text {Femployee }, t}\right) W F_{t} L_{F, t}
\end{aligned}
$$

Government spending is partly on domestic goods $G_{H t}$ and partly on foreign goods $G_{f(t}$.

$$
\begin{aligned}
G_{H t} & =\alpha G_{t}\left(\frac{P_{F t t}}{P_{I N V t}}\right)^{-\eta} \\
G_{f I t} & =\square-\alpha G_{t}\left(\frac{P_{f t t}}{P_{I N V t}}\right)^{-\eta}
\end{aligned}
$$


Fiscal policy is geared at keeping the public debt to GDP ratio $\frac{D e b t_{t}}{Z Z_{t}}$ fluctuating around a steady state value DEBTGDPbar.

$$
\begin{aligned}
& \log \left(\frac{\text { Debt }_{t}}{Z Z_{t}}\right)=(\square-r h o t a x F) \square \log (\text { DEBTGDPbar }) \\
& +\operatorname{rhotax} F \square \log \left(\frac{\text { Debt }_{t-\square}}{Z Z_{t-\square}}\right)+e p s \operatorname{Pax}_{t}
\end{aligned}
$$

Similarly, the government spending to GDP ratio is kept around a given policy level Gbar.

$$
\log \left(\frac{G}{Z Z}\right) \square=(\square-r h o G) \square \log (\text { Gbar })+r h o G \square \log \left(\frac{G_{t-\square}}{Z Z_{t-\square}}\right)+e p s G_{t}
$$

And labor tax rates for employer and employees and the unemployment allowance are kept stable around fixed levels ( taxF $\square$ employeebar and WUbar). The fiscal adjustment takes place on the lump-sum taxes $\operatorname{Tax}_{t}$.

$\log \left(\operatorname{tax} F \square\right.$ employee $\left._{t}\right) \square=(\square-\operatorname{rhotax} F) \square \log (\operatorname{tax} F \square$ employeebar $)$

$+\operatorname{rhotax} F \square \log \left(\operatorname{tax} F \square\right.$ employee $\left.e_{t-\square}\right)+$ epstax $F \square$ employee $_{t}$

$\log \left(W U_{t}\right) \sqsubset=(\square-\operatorname{rhoWU}) \square \log (W U b a r)+\operatorname{rhoWU} \square \log \left(W U_{t-\square}\right)+\operatorname{eps} W U_{t} \square$

\section{Monetary Policy}

The central bank follows an inflation targeting regime with a policy reaction function that cares about interest rate smoothing and cares about deviations of inflation and output from their steady state levels.

$$
\begin{aligned}
& \log \left(\square+i_{t}\right)-\log \left(\square+i^{S S}\right) \mp=\operatorname{gammai} \square\left(\log \left(\square+i_{t-\square}\right)-\log \left(\square+i^{S S}\right)\right) \\
& +(\square-\text { gammai }) \square\left(\begin{array}{l}
\operatorname{gammaPIE} \square\left(\log (P I E)-\log \left(P I E^{S S}\right)\right) \\
+\operatorname{gammaY} \square\left(\log (Z Z)-\log \left(Z Z^{S S}\right)\right)
\end{array}\right)+\text { epsi } \square
\end{aligned}
$$




\section{Market clearing}

The demand for formal goods $Q D F_{t}$ is equal to the sum of formal consumption goods $C F_{t}$, formal goods used for investment $I H_{t}$, formal goods used for government consumption $G H_{t}$ and formal goods exported $Q X_{t} \cdot Q D F_{t}=C F_{t}+I H_{t}+G H_{t}+Q X_{t}$ in contrast, the demand for informal goods $Q D I_{t}$ is only used to satisfy the consumption demand of informal goods $C I_{t}$. $Q D I_{t}=C I_{t}$

At the aggregate level, the hiring costs and firm entry costs generate frictions that create a wedge between the production of formal and informal goods and the demand for both goods, explaining why reducing those frictions can increase both production and consumption.

$$
\begin{gathered}
Y F_{t}=Q D F_{t}+\frac{H C F_{t} \square H F_{t}}{\frac{P F P P_{t}}{P H P_{t}}}+\frac{N F E_{t} \square E N T R Y N F_{t}}{\frac{P F P P_{t}}{P H P_{t}}}+\frac{d F_{t}}{\square} \square\left(\frac{P F P_{t}}{P F P_{t-\square}} \square \frac{P I E H_{t}}{P I E^{S S}}-\square\right) \square \frac{Q D F s_{t}}{\frac{P F P P_{t}}{P H P_{t}} \square N F_{t}} \\
Y I_{t}+Y H P_{t}=Q D I_{t}+\frac{H C I_{t} \square H I_{t}}{\frac{P I P P_{t}}{P H P_{t}}}+\frac{N I E_{t} \square E N T R Y N I_{t}}{\frac{P I P P_{t}}{P H P_{t}}}+\frac{d I_{t}}{\square} \square\left(\frac{P I P_{t}}{P I P_{t-\square}} \square \frac{P I E H_{t}}{P I E^{S S}}-\square\right) \frac{\square D I s_{t}}{\frac{P I P P_{t}}{P H P_{t}}} \square N I_{t}
\end{gathered}
$$

GDP is defined as usual, adjusting the components by their relative prices:

$$
Z Z_{t} \sqsubset \mathbb{C}_{t}+\frac{P F P P_{t} \square P H P_{t}}{P H P P \square I_{t}} \square\left(I_{t}+G_{t}\right)+P F P P_{t} \square P H P_{t} \square Q X_{t}-P_{P P P} \square Q M_{t}
$$


Annex II. Evaluating the Steady State of the Model

\begin{tabular}{|c|c|c|c|c|c|}
\hline \multirow{2}{*}{ Variable } & \multicolumn{3}{|c|}{ Data (percent) } & \multirow{2}{*}{$\begin{array}{c}\text { Data source and } \\
\text { coverage } \\
\end{array}$} & \multirow{2}{*}{$\begin{array}{c}\text { Model } \\
\text { (percent) }\end{array}$} \\
\hline & Average & Min & Max & & \\
\hline $\begin{array}{l}\text { Investment as a share of } \\
\text { GDP }\end{array}$ & 32.1 & 26.4 & 39.1 & HCP 2000-2017 & 31.7 \\
\hline $\begin{array}{l}\text { Household consumption } \\
\text { as a share of GDP }\end{array}$ & 58.5 & 56.5 & 61.6 & HCP 2000-2017 & 58.6 \\
\hline $\begin{array}{l}\text { Public consumption as a } \\
\text { share of GDP }\end{array}$ & 18.4 & 16.8 & 19.9 & HCP 2000-2017 & 18.3 \\
\hline $\begin{array}{l}\text { Imports of goods and } \\
\text { services as a share of GDP }\end{array}$ & 41.1 & 30.8 & 50.2 & HCP 2000-2017 & 40.4 \\
\hline $\begin{array}{l}\text { Exports of goods and } \\
\text { services as a share of GDP }\end{array}$ & 32.1 & 26.8 & 37.1 & HCP 2000-2017 & 31.7 \\
\hline Unemployment rate & 10.2 & 8.9 & 13.4 & HCP 2000-2017 & 10.2 \\
\hline $\begin{array}{l}\text { Shadow economy as a } \\
\text { share of GDP }\end{array}$ & 17.9 & $11.5^{*}$ & $24.2^{\star *}$ & HCP-2013/2014 & 17.9 \\
\hline $\begin{array}{l}\text { Shadow economy as a } \\
\text { share of total employment }\end{array}$ & 37.3 & $22.1^{\star}$ & $52.5^{\star *}$ & HCP 2013/2014 & 45.4 \\
\hline
\end{tabular}

Note: * means excluding agriculture, ${ }^{* *}$ means including agriculture. 


\section{Annex III. Calibration of Steady State Parameters ${ }^{1}$}

\begin{tabular}{|c|c|c|}
\hline Name of parameter/variable & Value & Source \\
\hline Discount rate & 0.98 & Ba s ed on historical data (2000-2017) \\
\hline Physical capital depreciation ra te & 0.045 & Ba s ed on historical data (2000-2017) \\
\hline Formal capital income share & 0.5 & Bas ed on historical data (2000-2017) \\
\hline Informal ca pital income s hare & 0.1 & Bas ed on historical data (2000-2017) \\
\hline Home inflation $(\%, y-0-y)$ & 2 & HCP (2000-2017) \\
\hline Exit ra te of formal retailers & 0.32 & $\begin{array}{l}\text { Authors' calculations based on bankruptcy data from HCP } \\
\text { a nd Inforisk }\end{array}$ \\
\hline Exit rate of informal retailers & 0.5 & $\begin{array}{l}\text { Ass umed to be } 50 \text { percent higher than in the formal } \\
\text { s ector }\end{array}$ \\
\hline Firing probability in the formal sector & 0.15 & $\begin{array}{l}\text { Authors' calculations based on employment data from } \\
\text { HCP (2000-2017) }\end{array}$ \\
\hline Firing probability in the informal sector & 0.45 & $\begin{array}{l}\text { Authors' calculations based on em ployment data from } \\
\text { HCP (2000-2017) }\end{array}$ \\
\hline Ra ti o of hiring cost to wage in the formal sector & 1.75 & $\begin{array}{l}\text { Global Competitiveness Index, World Bank Doing } \\
\text { Business, a nd ILO }\end{array}$ \\
\hline Ra tio of hiring cost to wage in the informal sector & 0.44 & Ass umed to be $1 / 4$ of formal hiring cost \\
\hline $\begin{array}{l}\text { Ela sticity of s ubstitution between home and foreign } \\
\text { goods }\end{array}$ & 0.6 & Ait Lahcen (2014) \\
\hline Home bias & 0.8 & Authors' calculation based on trade data (HCP 2000-2017) \\
\hline Export price elasticity & 2 & Tra de Ministry, World Bank (2012), a nd Abbad (2017) \\
\hline Sha re of income ta $x$ revenue to GDP (\%) & 0.04 & Ministry of Finance (2000-2017) \\
\hline Exchange rate pass-through to import prices & 0.4 & $\begin{array}{l}\text { Goldfajn and Werlang (2000), a nd Abida and Sghaier } \\
\text { (2012) }\end{array}$ \\
\hline $\begin{array}{l}\text { Entry cost in the formal sector (in months of } \\
\text { production) }\end{array}$ & 2.07 & $\begin{array}{l}\text { World Bank Doing Business, World Economic Forum, and } \\
\text { a uthors' calculation. }\end{array}$ \\
\hline $\begin{array}{l}\text { Entry cost in the informal sector (in months of } \\
\text { production) }\end{array}$ & 0.52 & As s umed to be $1 / 4$ of formal entry cost \\
\hline $\begin{array}{l}\text { Ela sticity of hiring cost wrt to hiring probability in the } \\
\text { formal sector }\end{array}$ & 0.5 & Munkacsi and Saxegaard (2017) \\
\hline $\begin{array}{l}\text { Ela sticity of hiring cost wrt to hiring probability in the } \\
\text { informal sector }\end{array}$ & 0.5 & Munkacsi and Saxegaard (2017) \\
\hline $\begin{array}{l}\text { Ela sticity of substitution between the formal and } \\
\text { informal goods }\end{array}$ & 1.5 & Authors' calculations based on HCP data (2000-2017) \\
\hline Formal bargaining power of workers & 0.5 & Calibrated to match the unemployment rate \\
\hline Informal bargaining power of workers & 0.1 & $\begin{array}{l}\text { Calibrated to match the unemployment rate and lower } \\
\text { than in the formal sector }\end{array}$ \\
\hline
\end{tabular}

${ }^{1}$ Several robustness checks were perfo rmed to ensure that the main findings are not sensitive to the assumptions made to calibrate the steady state.
} 


\section{Annex IV: Measuring the Size of the Informal Economy in Morocco}

The literature distinguishes between direct and indirect approaches to measure the size of the informal economy. Direct approaches are micro-founded, i.e., based on different sets of samples and surveys, and they usually adopt a strict definition of the informal sector. These approaches rely on voluntary replies and remain sensitive to the cooperation and willingness of respondents. Indirect approaches are usually macro-founded which means that they are based on several assumptions on the causes and effects of the informal economy and include all forms of the shadow economy.

- $\quad$ Direct approaches. Several statistical surveys have focused on the size of the informal sector in Morocco, with different definitions considering the size of the production units, the number of employees, the compliance with the tax law, and/or the social security requirements. These differences are motivated by the purpose of each investigation. The High Commission for Planning conducted three national surveys on the informal economy in the last two decades (in 2000, 2007, and 2014). Informal units are defined in these surveys as production units that do not have a formal accounting system. These surveys cover all sectors excluding agriculture for which a specific survey is available.

- Indirect approaches. A growing empirical literature identifies several sets of indirect measures of the informal economy. These measures have the advantage of providing dynamic estimates and being more suited for macroeconomic analysis. For example, Schneider (2012) identifies the size of the informal economy in 162 countries (including Morocco) using a Multiple Indicators Multiple Causes (MIMIC) approach. He finds that the informal sector in Morocco declined from 36.5 percent of GDP in 1999 to 33.1 percent in 2007 and averaged at 34.9 percent over the entire period. Elgin and Oztunali (2012) present a two-sector dynamic general equilibrium model to estimate the size of the informal economy for 161 countries. The results for Morocco indicate that the informal sector's share in total GDP decreased from 35.6 percent in 2000 to 32.6 percent in 2008 and averaged at 34.2 percent of GDP. Medina and Schneider (2018) estimated the size of the informal sector for 158 countries between 1991 and 2015 using the currency demand and the MIMIC approaches. In Morocco, they claim that the informal sector averaged 34 percent of GDP between 1991 and 2015 (31.4 between 2000 and 2014), with a maximum of 40.4 percent in 1995 and a minimum of 27.1 percent in 2015.

CInternational Monetary Fund. Not for Redistribution 